Boise State University

ScholarWorks

Political Science Faculty Publications and

Presentations

Department of Political Science

9-1-2014

Public Management in Political Institutions: Explaining Perceptions of White House Chief of Staff Influence

José D. Villalobos

University of Texas at El Paso

Justin S. Vaughn

Boise State University

David B. Cohen

University of Akron 


\title{
PUBLIC MANAGEMENT IN POLITICAL INSTITUTIONS: EXPLAINING PERCEPTIONS OF WHITE HOUSE CHIEF OF STAFF INFLUENCE
}

\author{
José D. Villalobos \\ Assistant Professor \\ Political Science Department \\ University of Texas at El Paso \\ jdvillalobos2@utep.edu \\ (Contact Author) \\ Justin S. Vaughn \\ Assistant Professor \\ Boise State University \\ David B. Cohen \\ Professor \\ University of Akron
}

\begin{abstract}
The notion that public managers influence organizational performance is common in public administration research. However, less is known about why some managers are better at influencing organizational performance than others. Furthermore, relatively few studies have systematically examined managerial influence and scholars have yet to investigate either quantitatively or systematically managerial influence in the White House. Utilizing original survey data collected from former White House officials who served in the Reagan, George H.W. Bush, and Clinton administrations, this study applies empirical public management theory to examine for the first time the key determinants that shape perceptions of chief of staff managerial influence. The findings demonstrate how several core concepts in public management theory help explain the dynamics that drive perceptions of managerial influence, thereby providing a new contribution to the literature on public management.
\end{abstract}

Keywords: administrative presidency; chief of staff; managerial influence; public management

\section{INTRODUCTION}

During the summer of 1994, President Bill Clinton embarked on a major shake-up of his senior advisers when he replaced chief of staff Thomas F. 'Mack' McLarty III with then-budget director Leon E. Panetta (see Horvitz 1994). Over the previous year and a half, Clinton had developed a reputation for allowing too many advisers unfettered access to Oval Office meetings while McLarty—a lifelong friend and Washington outsider nicknamed 'Mack the Nice'-had been unable to control or correct the disorganization and miscommunication that ensued. By Clinton's own recollection, 'There used to be chaos around here. Every day we would have three, four meetings lasting hours and hours. I'd sit in them, and we'd make decisions like a committee. And every day I'd read about them in the papers. It got so that the public had an impression that I was indecisive' (Hamilton 2007, 468). Stepping in to rectify the situation, Panetta-known throughout the Washington Beltway for his management and negotiation skills—asserted himself in ending Clinton's open-ended bull sessions by streamlining the management of policy and personnel. Ultimately, Panetta's influence in redirecting operations at the White House and his continued leadership during his three-year tenure as chief of staff helped solidify his reputation among White House personnel (e.g., see Drew 1995; Hamilton 2007). 
The narrative that developed amid the transition from McLarty to Panetta implied that where McLarty appeared to lack influence in his managerial duties, Panetta was able to instill it over White House personnel as the succeeding chief of staff. But why, exactly, was Panetta perceived to be more influential than McLarty and how did his approach help set a new tone for changing the way business was conducted in the Clinton White House? In the broader context, what are the qualities and characteristics that formulate overall perceptions of chief of staff influence and how might such assessments connect and relate to White House organizational performance?

Although public administration scholars have long understood that managers possess significant potential for exerting influence over personnel and the functions of their organizations, relatively few studies have systematically examined why managers are perceived as influential or how such evaluations relate to organizational performance. Indeed, although previous studies on managerial influence have accumulated a great deal of knowledge through indepth qualitative examinations (McGregor 1974; Doig and Hargrove 1987; Hargrove and Glidewell 1990; Behn 1991; Thompson and Jones 1994; Ban 1995; Cohen and Eimicke 1995; Riccucci 1995; Holzer and Callahan 1998), only recently have scholars begun to utilize theoretical models and quantitative techniques to conduct more systematic research (e.g., O’Toole and Meier 1999; Meier and O’Toole 2011). Furthermore, scholars have rarely examined key political institutions in their attempts to uncover causal relationships between managerial actions and characteristics and their impact on the relevant organizations (but see Romzek 2000; Rosenthal and Bell 2003). This is particularly true concerning research on the institutional underpinnings of the contemporary American presidency, where although importing public administration theory to explain presidency-centric phenomena has become a somewhat standard practice (Arnold 1998; Robinson 2004; Hult and Walcott 2004; Walcott and Hult 1987, 1995, 2005; Vaughn and Villalobos 2009), studies on the managerial dimensions of the presidency have focused almost entirely on descriptive treatments of institutional arrangements, structural evolution, and personnel dynamics (e.g., Burke 2000; Patterson 1988, 2001; Kumar and Sullivan 2003).

In this study, we address this gap by applying a robust theoretical model to explain the dynamics that shape assessments of White House chief of staff management. The main contributions of this approach are three-fold: first, it extends the application of an established theoretical model to managerial rather than organizational-level performance; second, it expands the theoretical paradigms of public management into the analysis of the U.S. presidency; and, third, it yields important insights not only into management in the modern presidency, but also the political dynamics of administrative leadership more generally, with prospects for future application to other political institutions.

We conduct our study by applying measures of former White House officials' perceptions derived from the Chief of Staff Project (COSP) (Cohen 2002) to the key theoretical dimensions of the public management model developed by Kenneth J. Meier and Lawrence J. O’Toole, Jr. (Meier and O’Toole 2001, 2004; O’Toole and Meier 1999, 2003), hereafter referred to as the 'MO model.' The MO model is particularly useful for our purposes here as it allows scholars to identify the ways in which key management concepts affect managerial performance. In addition, by employing former White House officials' perceptions for our analyses, we are able to access indicators of influence otherwise unattainable. Our findings indicate that the core theoretical components of the MO model serve as robust predictors of individual-level dynamics that drive perceptions of managerial influence as they relate to executive performance.

\section{Managerial Influence: Theory and Empirics}

Every president since Richard Nixon has relied on a chief of staff (see Table 1). As Bradley Patterson (2001, pp. 119, 348) notes, chiefs of staff are burdened with the job of managing 'the whole institution of the White House,' essentially serving as a 'system manager: boss of none, but overseer of everything.' In other words, the White House chief of staff is the individual responsible for managing the bureaucracy that the president commands; the importance of the position is underscored by a rich body of scholarly knowledge about what it is chiefs of staff do (see Cohen 2002 for an extensive review). For instance, some scholars have examined the traditional roles of the chief of staff (e.g., administrator, advisor, guardian) and concluded that 'chiefs of staff who are effective in their major duties will have a positive impact on the administration' (Cohen 2002, p. 480; see also Cohen and Krause 2000; Cohen, Dolan, and Rosati 2002; Cohen, Hult, and Walcott 2012, Cohen, Vaughn, and Villalobos 2012). These major duties consist of a blend between managing and coordinating the administrative structure of the institutional presidency. In addition, chiefs of staff have been observed in the manner they sometimes become more directly involved with the work they oversee, such as in helping with negotiations on Capitol Hill (Patterson 2001, 
This is an author-produced, peer-reviewed version of this article. The final, definitive version of this document can be found online at Public

Administration, published by Wiley-Blackwell. Copyright restrictions may apply. doi: 10.1111/padm.12097

pp. 119-21). Nevertheless, attempts to examine chief of staff influence in a systematic manner have remained elusive. Here, we contend that the theoretical tools needed to begin producing this systematic, empirical knowledge already exist in public administration theory, particularly within the field of public management. Specifically, we argue that the leading determinants of organizational performance can also help explain the influence key managers in both public and political institutions wield within their organizations. This includes the White House chief of staff position, which represents arguably the highest ranking administrative position in a political institution in the United States.

[Insert Table 1 here]

To demonstrate this, we employ the MO model, which provides a platform for developing a rich theoretical explanation for the determinants of managerial influence and how they relate to administrative performance. In developing the MO model, Meier and O'Toole condense several decades of accumulated knowledge into a testable theory that identifies key factors related to organizational performance. In brief, the theory holds that organizational performance is a function of stability, internal and external management dynamics, and environmental factors. The thrust of the argument is that management matters; that is, leadership efforts made by organizational elites to maintain stability, exploit opportunities, and buffer organizational assets have an indelible impact on an organization's ability to serve its purpose. Whereas Meier and O’Toole (2007) have focused their efforts to explore the production of performance at an organizational level, we expand the model's reach to examine managerial-level performance metrics. In that vein, we build on Meier and O'Toole's previous work by focusing our efforts on an empirical examination of the various components of their theory, which is expressed in mathematical form as follows:

$$
\mathrm{O}_{\mathrm{t}}=\beta_{1}\left(\mathrm{~S}+\mathrm{M}_{1}\right) \mathrm{O}_{\mathrm{t}-1}+\beta_{2}\left(\mathrm{X}_{\mathrm{t}} / \mathrm{S}\right)\left(\mathrm{M}_{3} / \mathrm{M}_{4}\right)+\varepsilon_{\mathrm{t}}
$$

For this equation, $\mathrm{O}$ denotes a measure for organizational performance, $\mathrm{S}$ is a measure of stability, and $\mathrm{M}$ denotes management. Internal management $\left(\mathrm{M}_{1}\right)$ denotes management's contribution to stability through alterations to organizational structure and operations. External management $\left(\mathrm{M}_{2}\right)$ represents a balance between an organization's networking versus risk-averse buffering efforts. Although $\mathrm{M}_{2}$ is not explicitly included in the MO model, its two components- $\mathrm{M}_{3}$ and $\mathrm{M}_{4}$-are featured independently, with $\mathrm{M}_{3}$ representing managerial efforts to exploit the environment of the organization, and $\mathrm{M}_{4}$ representing managerial efforts to buffer the unit from environmental influences. $\mathrm{X}$ is a vector of environmental forces, $\varepsilon$ is an error term, the other subscripts denote time periods, and $\beta_{1}$ and $\beta_{2}$ are estimable parameters. In all, the components of the MO model described above hold that organizational performance is a function of how management balances internal dynamics with a diffuse external environment.

Our study focuses on examining managerial influence, which signifies a major dimension of chief of staff performance that can be explained by the same factors previous research has shown drives organizational performance. We base this contention on the logic that the role managers play (i.e., in applying a particular organizational structure and coordinating style, affecting relations between personnel, controlling and vetting information flow and access, etc.) collectively captures a significant share of what shapes overall White House performance. Indeed, as Walcott and Hult (1995, 2005; see also Hult and Walcott 2004) note, chief of staff performance is largely dependent on the chief's ability to leverage the strengths of the organization and external assets against internal challenges and outside forces, such that performance depends on being able to harness resources, navigate the encroaching organizational and oppositional hurdles, and ultimately produce achievements. From a personnel perspective, how staff members ultimately evaluate a manager should largely depend on how well they perceive managers are able to wield influence to meet the various expectations that come with such a role. Thus, just as key managerial dynamics affect the way institutions perform, so too should those same dynamics reflect how influential managers are perceived in their attempts to lead their organizations.

With respect to the position of chief of staff, no individual is better situated to influence the operation of a presidency, particularly given the gatekeeper role that provides full access to the president and the ability to control the access of other White House officials. The administrative position and gatekeeper role allow chiefs of staff to have a great amount of influence over the information flow and processes that presidents employ to make many of the decisions that shape executive performance. In the spirit of Light's (1984, p. 18) definition of influence as 'an advisor's ability to change outcomes from what they would have been,' we connect chief of staff influence to White House organizational performance. Accordingly, we test the extent to which variables representing the key 
theoretical components of the MO model, along with a number of contextual variables, drive White House personnel perceptions concerning a chief of staff's administrative influence as a proxy for White House organizational performance.

\section{Hypotheses}

The hypotheses we test in this study derive directly from the key components of the previously introduced MO model, the first of which is stability. Stability (S) refers to those elements that minimize interruptions in bureaucratic production and promote 'constancy in the design, functioning, and direction of an administrative system over time' (Meier and O’Toole 2007, p. 506). O’Toole and Meier (2003) identify five separate types of stability: structural, mission, production (or technology), procedural, and personnel. Here, we focus on structural stability vis-à-vis White House organization as well as personnel stability as it relates to chief of staff experience, presidential experience, the chief of staff's working relationship with the president, and the chief of staff's working relationship with Congress.

Regarding how White House organization, as a measure of structural stability, may affect perceptions of chief of staff influence, we expect those who work for a chief of staff within a more clear-cut, hierarchical structure (rather than a less structured, 'spokes-of-the-wheel' approach) are more likely to have to depend on the chief of staff to get to the president. Similarly, a more hierarchical approach makes a president more reliant on the chief of staff to manage and control information flow. Accordingly, we hypothesize the more hierarchical the organization of the White House, the more influential the chief of staff is likely to be perceived (H1).

Another important factor that may condition chief of staff influence is experience. In referencing the benefits of experience, O'Toole and Meier (2003, p. 47) point out that 'multifaceted skills acquired in the trenches can make a significant difference in performance.' For our purposes, experience is defined as a chief of staff's general political background prior to coming to the White House. A lack of political experience may result in a learning period in a president's term during which a less experienced chief of staff may need to test numerous administrative approaches before settling on a particular managerial strategy. For personnel working in close quarters with a chief of staff who is unfamiliar with one's duties, managerial mistakes and changes in approach may lead to an unstable working environment characterized by a chief of staff who struggles to juggle the many managerial tasks at hand while trying to become familiar with the political games of the Beltway. Accordingly, we generally expect the more experience a chief of staff had in the political arena prior to one's tenure, the more influential the chief of staff is likely to be perceived (H2a). On the other hand, when considering presidential experience as it relates to chief of staff influence, it may be that a more experienced president is less likely to rely on the chief of staff such that the more experience a president had in the political arena prior to becoming president, the less influential his chief of staff is likely to be perceived (H2b).

Regarding a chief of staff's relationship with the president and Congress, we generally expect chiefs of staff with a more positive reputation in their dealings with both their boss and lawmakers in Congress are more likely to be able to engage with and influence such political actors. Accordingly, we expect the better the general working relationship between a chief of staff and a president, the more influential the chief of staff is likely to be perceived (H3a) and the better the general working relationship between a chief of staff and Congress, the more influential the chief of staff is likely to be perceived (H3b).

With respect to internal management $\left(\mathrm{M}_{1}\right)$, our focus here lies in determining the extent to which perceptions concerning more centralized chief of staff approaches tend to correlate positively with perceptions of managerial influence. It should be noted that this approach is different from testing the effects of actual measures of centralization (see Ponder 2000; Rudalevige 2002; Villalobos 2013). Although centralization is intrinsic to hierarchy, this study distinguishes between hierarchy as a perceptual measure of how structural stability affects the environment a chief of staff operates within versus perceptions of the type of centralized (or decentralized) role a chief of staff embraces in carrying out one's managerial duties. Accordingly, in terms of a chief of staff's administrative role, centralization depends on the extent to which a chief of staff is perceived as willing and able to coordinate the workings of the administration. We contend that personnel are likely to perceive chiefs of staff who seem to eschew their coordinating responsibilities as less influential compared to those who strongly embrace the 
role and attempt to use it as a means to direct the administrative agenda in a more straightforward, stable manner. Accordingly, we hypothesize the more a chief of staff embraces one's coordinating responsibilities, the more influential the chief of staff is likely to be perceived (H4).

Closely related to a chief of staff's administrative role is management style, which may vary from a hands-on chief of staff who spends a large amount of time on White House management issues to a chief of staff who prefers to delegate managerial responsibilities, the latter of which can lead to less stable structure and operations. Thus, we expect the more a chief of staff tends towards a hands-on management style, the more influential the chief of staff is likely to be perceived (H5a). In particular, a chief might be especially influential if the president prefers to delegate and therefore provides the chief of staff with greater discretion in directing White House operations. As such, we further hypothesize the less a president tends towards a hands-on management style, the more influential the chief of staff is likely to be perceived (H5b).

Our measures for networking $\left(\mathrm{M}_{3}\right)$ concern the extent to which personnel have access to both the chief of staff and the president. Opportunities derived (or restricted) due to accessibility may affect the extent to which personnel can advocate their preferences, provide advice and input for the decision-making process, and take on more responsibilities for an administration. We expect that a more accessible chief is more likely to be attentive in dealing with other personnel and involved in administrative affairs, thereby gaining a reputation for being a major player in an administration. Accordingly, we hypothesize the more accessible a chief of staff is, the more influential the chief of staff is likely to be perceived (H6a). Similarly, the less accessible the president, the more personnel staff may look to and depend on the chief of staff, and vice-versa. As such, we expect the less accessible a president is, the more influential the chief of staff is likely to be perceived (H6b). Accessibility aside, we also employ a chief of staff's level of visibility as an indicator of how well known and influential one is within an administration. Accordingly, we posit the more visible a chief of staff is as a public spokesperson for an administration, the more influential the chief of staff is likely to be perceived (H7).

With respect to buffering $\left(\mathrm{M}_{4}\right)$, we consider the manner in which a chief of staff may serve as a proxy for the president in order to perform tasks the president may be reluctant to perform himself, such as fighting political battles on behalf of the president and/or seeking to draw blame and criticism away from the president to protect that president's political interests. We also consider the extent to which a chief of staff may act as a 'reality-tester' by attempting to minimize a president's vulnerability to potential policy/political hazards by keeping the president fully informed of an administration's progress rather than trying to shield the president from any negative developments. As such, we hypothesize the more a chief of staff acts as a guardian or proxy for the president, the more influential the chief of staff is likely to be perceived (H8) and the more a chief of staff acts as a reality-tester for the president by actively attempting to warn the president of potential policy/political hazards, the more influential the chief of staff is likely to be perceived (H9).

Finally, the model accounts for the manner an organization's environment $(\mathrm{X})$ - that is, contextual factors such as constraints, resources, and external demands-may shape performance. For this, we develop several additional theoretical expectations, including: the organizational proximity between White House personnel and the chief of staff, whether government was divided, whether a major crisis took place during a chief of staff's tenure, and the manner in which presidential approval may have transferred to a particular chief. With regards to proximity, we expect a staffer's institutional position within the executive branch in relation to where the chief of staff operates within the White House may affect one's perception of chief of staff influence. Specifically, those proximate to the chief of staff are more likely to observe the chief of staff's efforts, as well as instances where the president looks to the chief for help and advice. As per the makeup of Congress, chiefs of staff serving at a time of divided government may find themselves more immersed in political negotiations with legislative opponents than those serving a president with majority support in the legislative branch. Accordingly, the additional challenges faced by a president under divided government may lead to greater dependence upon the chief of staff, which should increase perceptions of chief of staff influence. In addition, if a chief of staff is serving at a time of a major foreign policy crisis, such an event may have a significant influence on the manner in which one perceives the president and key members of the administration. Generally speaking, we expect White House personnel are likely to rally around a chief of staff during a time of crisis as a show of in-group unity, thereby bolstering the chief's perceived level of influence. Finally, the extent to which the public approves of the president's overall job performance (Edwards 
1990; Brace and Hinckley 1992, 1993) may also spill over to affect a staffer’s perceptions concerning chief of staff performance. Indeed, if the president is experiencing exceptionally high (or low) approval ratings, staff may connect such appraisals to the role the chief of staff has played in helping to run the administration.

\section{Using the MO Model and COSP Survey Data to Examine Managerial Influence}

The abstract nature of the MO model allows scholars to apply it to many different organizations for a variety of purposes, operationalizing performance as appropriate based on the function of the bureaucratic organization under examination and the nature of the research question. Indeed, in previous studies, the MO model has generated hypotheses for testing the determinants of organizational performance for bureaucracies as disparate as Texas school districts (Meier and O’Toole 2001, 2002, 2003), law enforcement agencies (Nicholson-Crotty and O’Toole 2004), and a wide assortment of municipal government services in the United Kingdom (Andrews et al. 2005). Here, by matching the key components of the MO model with measures of chief of staff-specific indicators, we are able to ensure a meaningful correspondence between the theoretical underpinnings of the model and the analyses reported in this study.

Because so much of what the chief of staff does happens behind closed doors, our use of former administration officials' perceptions provides us with a unique opportunity to uncover important new insights concerning the key factors that shape chief of staff managerial influence. Our approach falls in line with previous research demonstrating correlations between perceptual managerial and organizational performance indicators. Several studies indicate organizational performance may be predicted by a variety of perceptual managerial measures, including human resource management (Huselid 1995; Delaney and Huselid 1996), human capital measures (Gates and Langevin 2010), human resource bundles (MacDuffie 1995), intellectual capital indicators in management accounting (Tayles et al. 2007), employee motivations (DeVoe and Iyengar 2004), and organizational citizenship behaviors (Turnipseed and Rassuli 2005). Nevertheless, as with all observational studies, one should keep in mind that although variability on the dependent and independent variables between cases allows for an informed evaluation of the potential causal effects of our independent variables on chief of staff influence, our study does not include a pre-test/post-test structure (as in a controlled experiment) such that one cannot unequivocally confirm unidirectional causality for correlational relationships. Moreover, by employing White House staffers' perceptions of chief of staff influence we do not claim or imply that such measures represent actual chief of staff influence. Rather, our use of White House staff perceptions provide valuable proxy measures for better understanding White House organizational performance across different chiefs of staff and administrations. The inferences drawn from our findings and conclusions are reported within such confines and should be interpreted accordingly.

For our purposes, we match conceptually consistent data measuring White House personnel perceptions of chief of staff influence to the various nodes of the MO Model using the Chief of Staff Project (COSP) survey data. The COSP questionnaire was mailed in two stages to individuals listed in the White House Office (special assistant level and above), select positions within the Executive Office of the President (EOP) (i.e., Chair of the Council of Economic Advisers, Office of Management and Budget Director and Deputy Director, and the U.S. Representative to the United Nations), and cabinet and deputy cabinet officials that served in the Reagan, George H.W. Bush, and Clinton administrations.

The United States Government Manual was used as the primary source for determining COSP survey recipients. Respondents were asked to complete a 67-question survey for each chief of staff with whom they worked. Of the 776 individuals who were mailed surveys, 198 returned them, for an overall response rate of $25.5 \%$ (see Table 2 for a breakdown of personnel by administration and position served). Former Clinton officials had a $21.4 \%$ response rate, while $29.5 \%$ of the former Reagan-Bush officials who received questionnaires returned them. Some of these individuals served more than one chief of staff and/or position such that our sample constituted a total of 336 observations.

\section{[Insert Table 2 here]}

Within our sample, there was only one person for the White House/Cabinet Mixed position, leading us to exclude this position from the data analyses to avoid drawing any unreliable or invalid inferences from our findings. In addition, there were also a number of missing responses for some of the survey questions, resulting in an $\mathrm{N}$ of 296 for our main analyses. 
As previously mentioned, in explaining the determinants of managerial perceptions, we focus here on how key factors shape perceptions of chief of staff influence. Using a 7-point Likert-type scale ranging from no influence (1) to extremely influential (7), we measure perceptions of chief of staff influence in our analysis by asking: 'In sum, on a scale of 1 to 7, how much influence do you feel the COS [chief of staff] had while serving in the Administration?' All of our other main variables taken from the COSP questionnaire are measured in similar fashion (a supplemental appendix containing the full questionnaire is available at http://works.bepress.com/jdvillalobos/ and upon request).

In addition to the questionnaire measures, we also include measures of several key contextual factors mentioned above. For our measure of proximity to the chief of staff, we construct an ordinal control variable that measures the proximity to the chief of staff, where ' 1 ' denotes a cabinet level position, ' 2 ' denotes a mixed position, and ' 3 ' denotes a White House level position. Next, we measure divided government as a dichotomous variable where ' 1 ' denotes a time period for which divided government was present for the majority of a chief of staff's tenure and ' 0 ' otherwise. For the presence of a crisis, we assign a code of ' 1 ' for which a respondent who experiences at least one major foreign policy crisis during their tenure serving under a chief of staff and ' 0 ' otherwise.

Last, we measure presidential approval as the overall average percentage change for the duration of a given chief of staff's tenure in serving a president. Since the survey questions measure perceptions of a chief of staff's performance for the total time serving a given president, we operationalize our presidential approval measure to reflect aggregate measures of average change. Unfortunately, we are thus unable to disaggregate our presidential approval measures to reflect monthly or yearly changes in perception. Nevertheless, the multiple numbers of respondents for each of the chiefs we examine (e.g., 50 respondents for Leon Panetta) allows us to conduct robust cross-sectional analyses across multiple administrations and varying environmental conditions.

\section{Results}

Our analyses examine the tenures of ten White House chiefs of staff across three administrations from 1981 to 2001. For our main model, we estimate the data using ordered logit since our dependent variable is an ordinal survey response measure. We report robust standard errors clustered by chief of staff. Our unit of analysis is the response of a given former White House staff member. To account for any possible issues with endogeneity or multicollinearity in the data, we assessed the variance inflation factor (VIF) for our model to verify the validity and reliability of our empirical approach. The mean VIF value for our model is 1.98 and thus well below the VIF value of 10 that scholars consider to be the excess point for multicollinearity (Tables A1-A16 in the aforementioned supplemental appendix provide further information detailing the pair-wise correlations, descriptive statistics, and frequency distributions for all of our main variables).

The results for our main model shown in Table 3 suggest that some managerial dimensions matter more than others in determining perceptions of chief of staff influence. In particular, measures representing both stability (S) and external management $\left(\mathrm{M}_{2}\right)$ exhibited statistically significant relationships with our dependent variable, including: White House organization, a chief of staff's working relationship with both the president and Congress, the accessibility of both the chief of staff and the president, as well as measures of chief of staff visibility, guardianship of the president, and role as the president's reality-tester. Concerning our environmental controls, we also find that proximity, divided government, and the presence of a crisis further condition such perceptions. At the same time, none of our internal management $\left(\mathrm{M}_{1}\right)$ measures are related in a statistically significant way with chief of staff influence.

\section{[Insert Table 3 here]}

Regarding managerial stability, we find that the structural design in White House Organization, a chief of staff's relationship with the president, and the chief's relationship with Congress each significantly affect perceptions of chief of staff influence. Specifically, the minimum to maximum predicted probability results suggest that working within a more hierarchical organization may increase perceptions of chief of staff influence by 15.88 percentage points $(\mathrm{p}<.001)$. Meanwhile, the predictive probability results also suggest that chiefs having an excellent relationship with the president and Congress may increase perceptions of chief of staff influence by $23.23(\mathrm{p}<.001)$ and $10.1(\mathrm{p}<.05)$ percentage points, respectively. These results corroborate H1, H3a, and H3b. 
With regards to networking, the minimum to maximum predictive probability results indicate that chiefs of staff who are highly accessible are 6.01 percentage points more likely to be considered influential in networking directly with staff than those who are not $(\mathrm{p}<.05)$ while higher levels of presidential accessibility can limit a chief's ability to serve as a gatekeeper and may thereby lower perceptions of chief of staff influence by about 6.62 percentage points ( $<$.05), thus corroborating H6a and H6b. Regarding our third networking measure, we find that a chief of staff's visibility as a spokesman for the administration can further increase perceptions of their administrative influence. Specifically, the minimum to maximum predictive probability results indicate that extremely visible chiefs of staff are 15.51 percentage points more likely to be considered influential than less visible chiefs $(\mathrm{p}<.001)$, which corroborates $\mathrm{H} 7$.

Concerning our two buffering measures, we find that both chief of staff guardianship and a chief of staff's role in serving as a reality-tester have a suggestive, though only marginally significant $(p<.1)$, impact on enhancing officials' perceptions of chief of staff influence in an administration. In line with our expectations for H8, the minimum to maximum predictive probability results indicate that a chief of staff who acts largely as a guardian or proxy for the president is 8.52 percentage points more likely to be considered influential than one who does not. Likewise, in line with H9, the minimum to maximum predictive probability results indicate that chiefs who take on the role of reality-tester by actively attempting to warn the president of potential policy/political hazards are 10.91 percentage points more likely to be considered influential than those who do not embrace such role.

Managerial components aside, the results for our contextual variables suggest that closer proximity to the chief of staff may increase perceptions of influence while the presence of a crisis may lower perceptions, though these findings are only marginally significant $(\mathrm{p}<.1)$. More notably, our results show that a state of divided government increases the likelihood that a chief of staff will be perceived as more aggressively involved in dealing with congressional opponents and working to move the president's policy agenda through the legislative arena. Specifically, the minimum to maximum predictive probability results indicate that chiefs working during a state of divided government are about 8.98 percentage points more likely to be considered highly influential than those serving under a state of unified government $(\mathrm{p}<.05)$. These findings fall in line with transaction cost models of decision making for which one would expect the president to increase centralization of the policy process — often by employing the chief of staff to serve as a key negotiator-in competing with the legislative branch for control over policy development and, later, bureaucratic entities answering to multiple principals at the implementation stage.

\section{MO Model Applicability (Sensitivity Analysis)}

Apart from the main analysis we conduct to test our hypotheses, we also conduct a sensitivity analysis that employs index measures for each of the MO model components in order to test the validity of applying the MO model as our framework. To do this, we first performed an oblique rotation factor analysis for our main survey-based measures to determine how well the variables load — that is, how highly correlated they are with each of their corresponding MO model component subcategories (e.g., stability, internal management, networking, and buffering). The results of our factor analysis demonstrate that ten of our thirteen items loaded highly on their respective factors (see Table 4).

[Insert Tables 4-5 here]

To conduct a follow-up sensitivity analysis, we next constructed index measures for each of the MO component subcategories, leaving out the items that did not load well $(<.5)$. We then ran a new ordered logit regression analysis using the index measures for each of the MO model components and our environmental controls. The results of this sensitivity analysis were largely consistent and, in fact, stronger than that of our main model, thereby corroborating our application of the MO model framework in this study (see Table 5).

\section{Discussion and Conclusion}

Our study contributes to the literature on public management in a variety of ways. First, we have extended the application of an established theoretical model to managerial rather than organizational-level performance. We have also expanded the increasingly vital theoretical paradigms of public management into the field of presidential studies, thereby also extending management theory into the analysis of political institutions. Consequently, our study has yielded suggestive and important insights not only about management in the modern presidency but also the political dynamics of administrative leadership more generally. Furthermore, our findings and insights have 
This is an author-produced, peer-reviewed version of this article. The final, definitive version of this document can be found online at Public Administration, published by Wiley-Blackwell. Copyright restrictions may apply. doi: 10.1111/padm.12097

normative merit for policy makers, practitioners, and White House personnel interested in social science research concerning the traits, characteristics, and management practices that shape White House policy and political processes. As such, the application and expansion of our approach-both with respect to the White House as well as other organizational entities - provides a new template for better assessing managerial performance, one that moves away from the speculation so often circulated publicly by the media (or otherwise spread privately among key insiders) and more towards a systemic, objective means of evaluation.

In light of these findings, future studies should consider whether the general relationships identified here persist or change in important ways by expanding the application of our survey measures to include more recent chiefs of staff and developing and applying alternative chief of staff (and other White House) managerial performance measures. Subsequent survey samples should also extend beyond the White House proper to include a greater number of Cabinet members and their deputies. Scholars could then further examine the effect that proximity may have on personnel perceptions assuming that perceptions more closely track actual influence over outcomes for observers closer to the action. Scholars should likewise delve more deeply into the connections and distinctions between perceptual and direct performance indicators, including factors that can be objectively coded such as internal/external centralization of the policy process or political experience. Regarding the latter, one might consider the general correspondence and relative differences between the subjective, 7-point scale measures of presidential and chief of staff political experience we employ versus observable indicators measured in years (Tables A17-A33 in our supplemental appendix provide a full account of such measure comparisons, a list of all observed indicators, and the relevant descriptive statistics, both overall as well as individually for each of the presidents and chiefs of staff included in the analyses presented in this article).

Although not idiosyncratic, observable indicators may be limited in capturing the relative scope and significance of the kind of experience brought to the table in the way subjective perceptions can. For instance, Erskine Bowles had only four observable years of notable political experience prior to becoming chief of staff that included serving two years as White House Deputy Chief of Staff, reflected by a score of 4.06 (out of 7) from his peers on our subjective scale. By comparison, although Thomas McLarty logged more than twice as many observable years of prior political experience, his record rested on relatively less notable or relevant positions, including state legislator in Arkansas, chairman of the Arkansas State Democratic Party, and treasurer for Bill Clinton's failed gubernatorial bid in 1980, reflected by a lower score of 2.58 on our subjective scale. Given such comparative differences, the pros and cons of employing subjective versus objective measures for political experience (and other managerial performance indicators) merit further scholarly debate.

Researchers should also continue to explore other dimensions of chief of staff influence. For example, it would be interesting to examine differences in perceptions across policy domains. Given previous research on measures of presidential performance and accountability in the domestic versus foreign policy realms, much remains to be uncovered with respect to managerial questions across both domains. Scholars may also consider the manner in which chiefs of staff wield their influence. For instance, future studies may explore the difference between those chiefs of staff who take on a 'neutral broker' versus 'self-advocate' approach to managing the White House. Chiefs serving as neutral brokers presumably fit the mold of the 'passion for anonymity' that is often tied to public administrators who place organizational goals above politics and their own political agendas (Brownlow 1958). Meanwhile, chiefs of staff who act as self-advocates likely wield influence as power to affect outcomes, either with the primary intent to benefit their own agendas (which may not always be of benefit to overall organizational performance; e.g., Donald Regan) or perhaps to increase and maintain control of the bureaucratic apparatus with the primary intent to protect the interests of the White House and maximize organizational performance.

Scholars could further consider the differences between a chief of staff's political and policy influence in advising the president. In terms of how personnel view chief of staff managerial approaches, scholars may also move beyond general perceptions of overall influence to explore whether and to what extent White House officials vary in their perceptions of what constitutes a 'properly balanced' management approach (e.g., perhaps one that is neither too centralized nor too inattentive to subordinates' performance). Last, with regards to theory, scholars may also consider other literature employing different branches of public administration research, particularly pertaining to principal-agent models and studies on organizational hierarchy and information flow (e.g., Hammond and Miller 1985; Miller 1993; Wood and Waterman 1994; Hammond and Knott 1996; Waterman and Meier 1998; see also Rudalevige 2005; Walcott and Hult 2005). 
Future research could deepen understanding of how chiefs operate within the bureaucratic apparatus, how a chief's perceived managerial behavior and strategies reflect overall organizational performance perceptions and, ultimately, how such dynamics connect and contribute to tangible bureaucratic outputs and outcomes. In particular, this area of research will benefit greatly if scholars continue moving towards more direct measures of the dynamics that shape managerial performance, a more nuanced consideration of the relationship between perceptual performance measures and actual management practices and outputs, and more careful approximation and anchoring of such factors and their casual mechanisms.

\section{Acknowledgements}

We would like to express our gratitude to Ken Meier, Larry O’Toole, Cigdem Sirin, Holly Goerdel, Karen Hult, MaryAnne Borrelli, Wayne Steger, Victoria Farrar-Myers, Shirley Anne Warshaw, Nancy Kassop, Greg Hill, Morgen Johansen, Michael Mezey, and the anonymous reviewers for their instructive comments and generous advice. Any errors or omissions, however, are the sole responsibility of the authors. 


\section{References}

Andrews, R., G.A. Boyne, K.J. Meier, L.J. O’Toole and R. Walker. 2005. 'Representative Bureaucracy, Organizational Strategy, and Public Service Performance’, Journal of Public Administration Research and Theory, 15, 4, 489-504.

Arnold, P.E. 1998. Making the Managerial Presidency: Comprehensive Reorganization Planning, 1905-1980, 2nd edn. Princeton, NJ: Princeton University Press.

Ban, C. 1995. How do Public Managers Manage? San Francisco, CA: Jossey-Bass.

Behn, R. 1991. Leadership Counts. Cambridge, MA: Harvard University Press.

Brace, P. and B. Hinckley. 1992. Follow the Leader: Opinion Polls and the Modern Presidents. New York: Basic Books.

Brace, P. and B. Hinckley. 1993. 'Presidential Activities from Truman through Reagan: Timing and Impact', Journal of Politics, 55, 2, 382-98.

Brownlow, L. 1958. A Passion for Anonymity: The Autobiography of Louis Brownlow-Second Half. Chicano, IL: University of Chicago Press.

Burke, J.P. 2000. The Institutional Presidency: Organizing and Managing the White House from FDR to Clinton. Baltimore, MD: Johns Hopkins University Press.

Cohen, D.B. 2002. 'From the Fabulous Baker Boys to the Master of Disaster: The White House Chief of Staff in the Reagan and G.H.W. Bush Administrations’, Presidential Studies Quarterly, 32, 3, 463-83.

Cohen, D.B., C.J. Dolan and J.A. Rosati. 2002. 'A Place at the Table: The Emerging Foreign Policy Roles of the White House Chief of Staff', Congress \& the Presidency, 29, 2, 119-49.

Cohen, D.B., K.M. Hult and C. Walcott. 2012. 'The Chicago Clan: The Chiefs of Staff in the Obama White House', Social Science Quarterly, 93, 5, 1101-26.

Cohen, D.B. and G.A. Krause. 2000. 'Presidents, Chiefs of Staff, and the Structure of White House Organization: Survey Evidence from the Reagan and Bush Administrations', Presidential Studies Quarterly, 30, 3, 421-42.

Cohen, D.B., J.S. Vaughn and J.D. Villalobos. 2012. 'Manager-in-Chief: Applying Public Management Theory to Examine White House Chief of Staff Performance’, Political Research Quarterly, 65, 4, 841-54.

Cohen, S. and W.B. Eimicke. 1995. The New Effective Public Manager: Achieving Success in a Changing Government. San Francisco, CA: Jossey-Bass.

Delaney, J.T. and M.A. Huselid. 1996. 'The Impact of Human Resource Management Practices on Perceptions of Organizational Performance', Academy of Management Journal, 39, 4, 949-69.

DeVoe, S.E. and S.S. Iyengar. 2004. 'Managers' Theories of Subordinates: A Cross-Cultural Examination of Manager Perceptions of Motivation and Appraisal of Performance’, Organizational Behavior and Human Decision Processes, 93, 1, 47-61.

Doig, J.W. and E.C. Hargrove. 1987. Leadership and Innovation: A Biographical Perspective on Entrepreneurs in Government. Baltimore, MD: Johns Hopkins University Press.

Drew, E. 1995. On the Edge: The Clinton Presidency. New York: Touchstone.

Edwards, G.C., III. 1990. Presidential Approval. Baltimore, MD: Johns Hopkins University Press.

Gates, S. and P. Langevin. 2010. 'Human Capital Measures, Strategy, and Performance: HR Managers' Perceptions', Accounting, Auditing \& Accountability Journal, 23, 1, 111-32.

Hamilton, N. 2007. Bill Clinton: Mastering the Presidency. New York: PublicAffairs.

Hammond, T.H. and J.H. Knott. 1996. 'Who Controls the Bureaucracy?: Presidential Power, Congressional Dominance, Legal Constraints, and Bureaucratic Autonomy in a Model of Multi-Institutional Policymaking’, Journal of Law, Economics, and Organization, 12, 1, 119-66.

Hammond, T.H. and G.J. Miller. 1985. 'A Social Choice Perspective on Expertise and Authority in Bureaucracy', American Journal of Political Science, 29, 1, 1-28.

Hargrove, E.C. and J.C. Glidewell (eds). 1990. Impossible Jobs in Public Management. Lawrence, KS: University of Kansas Press.

Holzer, M. and K. Callahan. 1998. Government at Work: Best Practices and Model Programs. Thousand Oaks, CA: Sage.

Horvitz, P.F. 1994. 'Clinton Shuffles His Top Aides, Naming Panetta as Chief of Staff', New York Times, June 28: http://www.nytimes.com/1994/06/28/news/28iht-pres.html

Hult, K.M. and C.E. Walcott. 2004. Empowering the White House: Governance under Nixon, Ford, and Carter. Lawrence, KS: University Press of Kansas.

Huselid, M.A. 1995. 'The Impact of Human Resource Management Practices on Turnover, Productivity, and Corporate Financial Performance’, The Academy of Management Journal, 38, 3, 635-72. 
Kumar, M.J. and T. Sullivan. 2003. The White House World: Transitions, Organization, and Office Operations. College Station, TX: Texas A\&M University Press.

Light, P.C. 1984. Vice-Presidential Power: Advice and Influence in the White House. Baltimore, MD: Johns Hopkins University Press.

MacDuffie, J.P. 1995. 'Human Resource Bundles and Manufacturing Performance: Organizational Logic and Flexible Production Systems in the World Auto Industry', Industrial and Labor Relations Review, 48, 2, 197221.

McGregor, E.B., Jr. 1974. 'Politics and the Career Mobility of Bureaucrats', American Political Science Review, 68, $1,18-26$.

Meier, K.J. and L.J. O’Toole, Jr. 2001. 'Managerial Strategies and Behavior in Networks: A Model with Evidence from U.S. Public Education', Journal of Public Administration Research and Theory, 11, 3, 271-95.

Meier, K.J. and L.J. O’Toole, Jr. 2002. 'Public Management and Organizational Performance: The Effect of Managerial Quality', Journal of Policy Analysis and Management, 21, 4, 629-40.

Meier, K.J. and L.J. O’Toole, Jr. 2003. 'Public Management and Educational Performance: The Impact of Managerial Networking’, Public Administration Review, 63, 6, 675-85.

Meier, K.J. and L.J. O’Toole, Jr. 2004. 'Conceptual Issues in Modeling and Measuring Management and its Impacts on Performance', In The Art of Governance: Analyzing Management and Administration, Ingraham, P. and L.E. Lynn, Jr. (eds), 195-223. Washington, DC: Georgetown University Press.

Meier, K.J. and L.J. O’Toole, Jr. 2007. 'Modeling Public Management: Empirical Analysis of the ManagementPerformance Nexus’, Public Management Review, 9, 4, 503-27.

Meier, K.J. and L.J. O’Toole, Jr. 2011. Public Management: Organizations, Governance, and Performance. Cambridge, MA: Cambridge University Press.

Miller, G.J. 1993. Managerial Dilemmas: The Political Economy of Hierarchy. Cambridge, MA: Cambridge University Press.

Nicholson-Crotty, S. and L.J. O'Toole, Jr. 2004. 'Testing a Model of Public Management and Organizational Performance: The Case of Law Enforcement Agencies', Journal of Public Administration Research and Theory, 14, 1, 1-18.

O’Toole, L.J., Jr. and K.J. Meier. 1999. 'Modeling the Impact of Public Management: The Implications of Structural Context', Journal of Public Administration Research and Theory, 9, 4, 505-26.

O’Toole, L.J., Jr. and K.J. Meier. 2003. ‘Plus Ça Change: Public Management, Personnel Stability, and Organizational Performance', Journal of Public Administration Research and Theory, 13, 1, 43-64.

Patterson, B.H. 1988. The Ring of Power: The White House Staff and its Expanding Role in Government. New York: Basic Books.

Patterson, B.H. 2001. The White House Staff: Inside the West Wing and Beyond. Washington, DC: Brookings Institution Press.

Ponder, D.E. Good Advice: Information and Policy Making in the White House. College Station, TX: Texas A\&M University Press.

Riccucci, N.M. 1995. Unsung Heroes: Federal Executives Making a Difference. Washington, DC: Georgetown University Press.

Robinson, S.E. 2004. 'The President as Reformer: When Do Presidents Initiate Administrative Reform through Legislation?’, Presidential Studies Quarterly, 34, 4, 793-803.

Romzek, B.S. 2000. 'Accountability of Congressional Staff', Journal of Public Administration Research and Theory, 10, 3, 413-46.

Rosenthal, C.S. and L.C. Bell. 2003. 'From Passive to Active Representation: The Case of Women Congressional Staff', Journal of Public Administration Research and Theory, 13, 1, 65-82.

Rudalevige, A. 2002. Managing the President's Program: Presidential Leadership and Legislative Policy Formulation. Princeton, NJ: Princeton University Press.

Rudalevige, A. 2005. 'The Structure of Leadership: Presidents, Hierarchies, and Information Flow', Presidential Studies Quarterly, 35, 2, 333-60.

Tayles, M., R.H. Pike and S. Sofian. 2007. 'Intellectual Capital, Management Accounting Practices and Corporate Performance: Perceptions of Managers’, Accounting, Auditing \& Accountability, 20, 4, 522-48.

Thompson, F. and L.R. Jones. 1994. Reinventing the Pentagon. San Francisco, CA: Jossey-Bass.

Turnipseed, D.L. and A. Rassuli. 2005. 'Performance Perceptions of Organizational Citizenship Behaviours at Work: A Bi-Level Study among Managers and Employees', British Journal of Management, 16, 3, 231-44.

Vaughn, J.S. and J.D. Villalobos. 2009. 'The Managing of the Presidency: Applying Theory-Driven Empirical Models to the Study of White House Bureaucratic Performance', Political Research Quarterly, 62, 1, 158-63. 
Villalobos, J.D. 2013. 'Agency Input as a Policy Making Tool: Analyzing the Influence of Agency Input on Presidential Policy Success in Congress', Administration \& Society, 45, 7, 837-74.

Walcott, C.E. and K.M. Hult. 1987. 'Organizing the White House: Structure, Environment, and Organizational Governance', American Journal of Political Science, 31, 1, 109-25.

Walcott, C.E. and K.M. Hult. 1995. Governing the White House: Hoover through LBJ. Lawrence, KA: University Press of Kansas.

Walcott, C.E. and K.M. Hult. 2005. 'White House Structure and Decision Making: Elaborating the Standard Model', Presidential Studies Quarterly, 35, 2, 303-18.

Waterman, R.W. and K.J. Meier. 1998. 'Principal-Agent Models: An Expansion?’, Journal of Public Administration Research and Theory, 8, 2, 173-202.

Wood, B.D. and R.W. Waterman. 1994. Bureaucratic Dynamics: The Role of Bureaucracy in a Democracy. Boulder, CO: Westview Press. 
Table 1 White House Chiefs of Staff in the Modern Era, 1969-2014*

\begin{tabular}{llll}
\hline Chief of Staff & Tenure & President & Party \\
\hline Harry Robbins Haldeman & $1969-73$ & Richard M. Nixon & Republican \\
Alexander M. Haig, Jr. & $1973-74$ & Richard M. Nixon & Republican \\
Donald H. Rumsfeld & $1974-75$ & Gerald Ford & Republican \\
Richard M. Cheney & $1975-77$ & Gerald Ford & Republican \\
William H.M. Jordan & $1979-80$ & Jimmy Carter & Democrat \\
Jack H. Watson, Jr. & $1980-81$ & Jimmy Carter & Democrat \\
James A. Baker III & $\mathbf{1 9 8 1 - 8 5}$ & Ronald Reagan & Republican \\
Donald T. Regan & $\mathbf{1 9 8 5 - 8 7}$ & Ronald Reagan & Republican \\
Howard H. Baker, Jr. & $\mathbf{1 9 8 7 - 8 8}$ & Ronald Reagan & Republican \\
Kenneth M. Duberstein & $\mathbf{1 9 8 8 - 8 9}$ & Ronald Reagan & Republican \\
John H. Sununu & $\mathbf{1 9 8 9 - 9 1}$ & George H.W. Bush & Republican \\
Samuel K. Skinner & $\mathbf{1 9 9 1 - 9 2}$ & George H.W. Bush & Republican \\
James A. Baker III** & $1992-93$ & George H.W. Bush & Republican \\
Thomas F. McLarty III & $\mathbf{1 9 9 3 - 9 4}$ & Bill Clinton & Democrat \\
Leon E. Panetta & $\mathbf{1 9 9 4 - 9 7}$ & Bill Clinton & Democrat \\
Erskine B. Bowles & $\mathbf{1 9 9 7 - 9 8}$ & Bill Clinton & Democrat \\
John D. Podesta & $\mathbf{1 9 9 8 - 0 1}$ & Bill Clinton & Democrat \\
Andrew H. Card, Jr. & $2001-06$ & George W. Bush & Republican \\
Joshua B. Bolten & $2006-09$ & George W. Bush & Republican \\
Rahm I. Emanuel*** & $2009-10$ & Barack Obama & Democrat \\
William M. Daley & $2011-12$ & Barack Obama & Democrat \\
Jacob Lew & $2012-13$ & Barack Obama & Democrat \\
Denis McDonough & $2013-p r e s e n t ~$ & Barack Obama & Democrat \\
\hline *COSP data includes personnel for those chiefs of staff shown in bold text. & \\
** James Baker’s brief second stint as chief of staff is excluded from our analyses. \\
***After Emanuel left his post to run for mayor of Chicago, Peter M. Rouse stepped in briefly \\
as 'acting' chief of staff from October 1, 2010 to January 13, 2011. & \\
\hline
\end{tabular}

Table 2 Chief of Staff Project (COSP): Personnel by Position Level

\begin{tabular}{lcccc}
\hline Position Level & Reagan & Bush & Clinton & Total \\
\hline White House Assistant & 30 & 11 & 35 & 76 \\
White House Deputy Assistant & 28 & 17 & 47 & 92 \\
White House Special Assistant & 49 & 12 & 48 & 109 \\
White House Mixed & 3 & 0 & 2 & 5 \\
White House/Cabinet Mixed & 1 & 0 & 0 & 1 \\
Inner Cabinet & 2 & 1 & 0 & 3 \\
Inner Cabinet Deputy & 2 & 0 & 5 & 7 \\
Outer Cabinet & 3 & 4 & 5 & 12 \\
Outer Cabinet Deputy & 6 & 5 & 20 & 31 \\
\hline Total & 123 & 50 & 162 & 336
\end{tabular}


Table 3 Examining Perceptions of Chief of Staff Influence (Ordered Logit Regression with Robust Standard Errors Clustered by COS)

\begin{tabular}{|c|c|c|c|c|}
\hline Independent Variables & Coefficients & Z-Score & Min->Max & + -sd/2 \\
\hline \multicolumn{5}{|l|}{ Stability (S) } \\
\hline White House Organization & $.419 * * *(.129)$ & 3.26 & .1588 & .0402 \\
\hline COS Experience & $-.032(.111)$ & -.29 & - & - \\
\hline POTUS Experience & $.075(.234)$ & .32 & - & - \\
\hline COS Working Relationship w/POTUS & $1.021^{* * *}(.143)$ & 7.14 & .2323 & .0682 \\
\hline COS Working Relationship w/Congress & $.254 * *(.11)$ & 2.31 & .1010 & .0274 \\
\hline \multicolumn{5}{|l|}{ Internal Management $\left(\mathbf{M}_{1}\right)$} \\
\hline COS Administrator Role & $.156(.182)$ & .86 & - & - \\
\hline COS Management Style & $.04(.077)$ & .53 & - & - \\
\hline POTUS Management Style & $-.04(.076)$ & -.52 & - & - \\
\hline \multicolumn{5}{|l|}{ External Management (M $\left.\mathbf{M}_{2}\right)$} \\
\hline COS Accessibility $\left(\mathrm{M}_{3}\right)$ & $.149 * *(.09)$ & 1.66 & .0601 & .0157 \\
\hline POTUS Accessibility $\left(\mathrm{M}_{3}\right)$ & $-.178^{* *}(.086)$ & -2.09 & .0662 & .0218 \\
\hline COS Visibility $\left(\mathrm{M}_{3}\right)$ & $.414 * * *(.121)$ & 3.43 & .1551 & .0422 \\
\hline COS Guardianship $\left(\mathrm{M}_{4}\right)$ & $.213 *(.133)$ & 1.60 & .0852 & .0200 \\
\hline COS Reality-Tester $\left(\mathrm{M}_{4}\right)$ & $.275 *(.203)$ & 1.36 & .1091 & .0280 \\
\hline \multicolumn{5}{|l|}{ Environmental Controls (X) } \\
\hline Proximity to the COS & $.258 *(.197)$ & 1.31 & .0348 & .0117 \\
\hline Divided Government $(1,0)$ & $1.312 * *(.664)$ & 1.98 & .0898 & $\mathrm{NA}^{\dagger}$ \\
\hline Crisis $(1,0)$ & $-.536 *(.326)$ & -1.65 & .0357 & $\mathrm{NA}^{\dagger}$ \\
\hline Presidential Approval & $-.047(.358)$ & -.13 & - & - \\
\hline $\mathrm{N}$ & 296 & & & \\
\hline Pseudo $\mathrm{R}^{2}$ & 3577 & & & \\
\hline
\end{tabular}

Dependent Variable: In sum, on a scale of 1 to 7, how much influence do you feel the COS [chief of staff] had while serving in the Administration?

† The predicted probability score for a half standard deviation above and below the mean is not applicable for the significant results of this variable since it is dichotomous.

$\mathrm{p}<.1^{*}, \mathrm{p}<.05^{* *}, \mathrm{p}<.001^{* * *}$

Table 4 Oblique Rotation Factor Analysis

\begin{tabular}{lll}
\hline & Factor 1(S) & Uniqueness \\
\hline White House Organization & .5239 & .7266 \\
Chief of Staff Experience & .8249 & .3262 \\
POTUS Experience & -.0926 & .0884 \\
COS Working Rel. w/POTUS & .5973 & .4922 \\
COS Working Rel. w/Congress & .8424 & .2985 \\
\hline & Factor 2 $\left(\mathrm{M}_{1}\right)$ & Uniqueness \\
\hline COS Administrator Role & .8415 & .2402 \\
COS Management Style & .8761 & .2229 \\
POTUS Management Style & .0070 & .0288 \\
\hline & Factor 3 $\left(\mathrm{M}_{3}\right)$ & Uniqueness \\
\hline COS Accessibility & .8595 & .2210 \\
POTUS Accessibility & .9033 & .1994 \\
COS Visibility & .0125 & .3751 \\
\hline & Factor 4 $\left(\mathrm{M}_{4}\right)$ & Uniqueness \\
\hline COS Guardianship & .8210 & .3261 \\
COS Reality-Tester & .8563 & .2700 \\
\hline
\end{tabular}


Table 5 Chief of Staff Influence Sensitivity Analysis with Index Measures (Ordered Logit Regression with Robust Standard Errors Clustered by COS)

\begin{tabular}{lcccc}
\hline Independent Variables & Coefficients & Z-Score & Min->Max & +-sd/2 \\
\hline MO Model Components & $1.02^{* * *}(.217)$ & 4.70 & .2384 & .0712 \\
$\quad$ Stability (S) & $.271^{* *}(.142)$ & 1.91 & .0996 & .0209 \\
Internal Mgt. $\left(\mathrm{M}_{1}\right)$ & $.273^{* *}(.14)$ & 1.94 & .0986 & .0149 \\
External Mgt. Networking $\left(\mathrm{M}_{3}\right)$ & $.728^{* * *}(.174)$ & 4.19 & .2178 & .0628 \\
External Mgt. Buffering (M4) & $.28^{* *}(.127)$ & 2.21 & .0380 & .0128 \\
Environmental Controls (X) & $1.4^{*}(1.042)$ & 1.34 & .0955 & $\mathrm{NA}^{\dagger}$ \\
$\quad$ Proximity to the COS & $-.382^{* *}(.223)$ & -1.71 & .0254 & $\mathrm{NA}^{\dagger}$ \\
Divided Government (1,0) & $.31(.539)$ & .58 & - & - \\
Crisis (1,0) & 296 & & & \\
Presidential Approval & .2971 & & & \\
N & & & \\
Pseudo R &
\end{tabular}

Dependent Variable: In sum, on a scale of 1 to 7, how much influence do you feel the COS [chief of staff] had while serving in the Administration?

${ }^{\dagger}$ The predicted probability score for a half standard deviation above and below the mean is not applicable for the significant results of this variable since it is dichotomous.

$\mathrm{p}<.1^{*}, \mathrm{p}<.05^{* *}, \mathrm{p}<.001^{* * *}$ 


\section{SUPPLEMENTAL APPENDIX*}

\section{WHITE HOUSE CHIEF OF STAFF PROJECT: COSP Questionnaire Guide (Likert Scale)}

We provide below the general introductory material used for the questionnaire, followed by the specific questions applicable to this study. The entire questionnaire that includes other items not applied to this particular study is available upon request.

\section{Biographical Information:}

Please list the titles and roles that you held, and the duties you performed, while serving in the administration, while was Chief of Staff (COS), and the approximate dates of your service in each of those capacities:

\section{Instructions:}

For each of the following questions, please circle a number between 1 and 7 which best represents your opinion. All answers to this survey will remain confidential (unless you specify otherwise). There is space at the bottom of each section in which you can make additional comments/suggestions if you would like.

\section{DEPENDENT VARIABLE}

\section{COS General Influence:}

In sum, on a scale of 1 to 7 , how much influence do you feel the COS had while serving in the administration?

$$
\text { Not Influential }
$$

$\begin{array}{lllllll}1 & 2 & 3 & 4 & 5 & 6 & 7\end{array}$

Extremely Influential

\section{INDEPENDENT VARIABLES}

\section{COS Experience:}

On a scale of 1 to 7, how would you characterize the COS's general political background prior to becoming COS (i.e., how much experience did the COS have in the political arena before becoming COS?)?

\begin{tabular}{cccccccc} 
No Political Experience & & & & \multicolumn{3}{c}{ Very Politically Experienced } \\
1 & 2 & 3 & 4 & 5 & 6 & 7
\end{tabular}

\section{POTUS Experience:}

On a scale of 1 to 7, how would you characterize the President's general political background prior to becoming President (i.e., how much experience did the President have in the political arena before becoming President?)?

No Political Experience
1
2
3
4
5

Very Politically Experienced

$\begin{array}{lr}\text { Very } & \text { Politica } \\ 6 & 7\end{array}$ 
This is an author-produced, peer-reviewed version of this article. The final, definitive version of this document can be found online at Public Administration, published by Wiley-Blackwell. Copyright restrictions may apply. doi: 10.1111/padm.12097

\section{White House Organization:}

On a scale of 1 to 7, how would you characterize the organization of the White House-hierarchical, with a strong COS in charge, a spokes-of-the-wheel system in which the president operated as his own COS, or something in between?

$$
\text { Spokes of the Wheel }
$$

$$
1
$$

2

3

COS Working Relationship w/POTUS:

On a scale of 1 to 7, how would you characterize the COS's general working relationship with the President?

Poor

$$
\begin{array}{lllllll}
1 & 2 & 3 & 4 & 5 & 6 & 7
\end{array}
$$

Excellent

COS Working Relationship w/POTUS:

On a scale of 1 to 7, how would you characterize the COS's general working relationship with the Congress?

Poor

$\begin{array}{lllllll}1 & 2 & 3 & 4 & 5 & 6 & 7\end{array}$

Excellent

COS Administrator Role:

On a scale of 1 to 7 , to what extent did the COS attempt to coordinate the White House administrative process (e.g., overseeing the President's schedule; ensuring the smooth operation of the White House)?

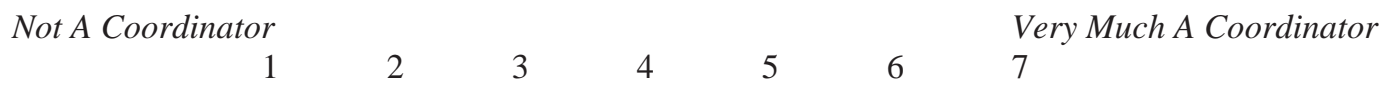

COS Accessibility:

On a scale of 1 to 7 , how accessible was the COS to you?

Not Accessible

$\begin{array}{lllllll}1 & 2 & 3 & 4 & 5 & 6 & 7\end{array}$

Extremely Accessible

\section{POTUS Accessibility:}

On a scale of 1 to 7 , how accessible was the President to you?

Not Accessible

$\begin{array}{lllllll}1 & 2 & 3 & 4 & 5 & 6 & 7\end{array}$

Extremely Accessible

COS Management Style:

On a scale of 1 to 7 , how would you characterize the COS's general style of managing the White House (i.e., how much time and involvement was spent by the COS on White House management issues?)?

Delegating

$\begin{array}{lllllllll}1 & 2 & 3 & 4 & 5 & 6 & 7 & \text { Hands-On }\end{array}$

\section{POTUS Management Style:}

On a scale of 1 to 7, how would you characterize the President's general style of managing the White House (i.e., how much time and involvement was spent by the President on White House management issues?)?

Delegating

$\begin{array}{llllllll}1 & 2 & 3 & 4 & 5 & 6 & 7\end{array}$

Hands-On 
This is an author-produced, peer-reviewed version of this article. The final, definitive version of this document can be found online at Public Administration, published by Wiley-Blackwell. Copyright restrictions may apply. doi: 10.1111/padm.12097

\section{COS Visibility:}

On a scale of 1 to 7 , how would you characterize the COS's visibility as a public spokesman for the Administration?

$$
\text { Not Visible }
$$

2

2

\section{COS Guardianship:}

On a scale of 1 to 7 , to what extent was the COS a proxy for the president who, among other things, performed tasks the President was reluctant to perform himself, fought political battles on the President's behalf, and sought to draw blame and criticism away from the President in an attempt to protect the President's political interests?

$$
\text { Not A Proxy }
$$

$$
2
$$$$
3
$$

4

5

6

7

Very Much A Proxy

\section{COS Reality-Tester:}

On a scale of 1 to 7, to what extent did the COS act as a reality-tester for the President by actively attempting to warn the President of potential policy/political hazards and giving him the 'bad news'?

Not A Reality-Tester
1
2

3

\section{4}

5
Very Much A Reality-Tester 
Table A1 Pair-Wise Correlations between COS Influence and the Main Explanatory Variables

\begin{tabular}{lr}
\hline COS Experience & COS Influence \\
POTUS Experience & .5129 \\
White House Organization & .0522 \\
COS Working Relationship w/POTUS & .5108 \\
COS Working Relationship w/Congress & .6059 \\
COS Administrator Role & .5393 \\
COS Management Style & .5241 \\
POTUS Management Style & .3785 \\
COS Accessibility & -.0978 \\
POTUS Accessibility & .1815 \\
COS Visibility & -.0034 \\
COS Guardianship & .5460 \\
COS Reality-Tester & .5564 \\
\hline
\end{tabular}


This is an author-produced, peer-reviewed version of this article. The final, definitive version of this document can be found online at Public Administration, published by Wiley-Blackwell. Copyright restrictions may apply. doi: 10.1111/padm.12097

Table A2 Pair-Wise Correlations between all Main Variables*

\begin{tabular}{|c|c|c|c|c|c|c|c|}
\hline & $\begin{array}{l}\text { COS } \\
\text { Influence }\end{array}$ & $\begin{array}{l}\text { COS } \\
\text { Experience }\end{array}$ & $\begin{array}{l}\text { POTUS } \\
\text { Experience }\end{array}$ & $\begin{array}{l}\text { White House } \\
\text { Organization }\end{array}$ & $\begin{array}{l}\text { COS Working } \\
\text { Rel. } \\
\text { w/POTUS }\end{array}$ & $\begin{array}{l}\text { COS Working } \\
\text { Rel. } \\
\text { w/Congress }\end{array}$ & $\begin{array}{l}\text { COS } \\
\text { Admin. } \\
\text { Role }\end{array}$ \\
\hline COS Influence & 1.0000 & & & & & & \\
\hline COS Experience & .5129 & 1.0000 & & & & & \\
\hline POTUS Experience & .0522 & .0006 & 1.0000 & & & & \\
\hline White House Organization & .5108 & .2898 & .0147 & 1.0000 & & & \\
\hline COS Working Rel. w/POTUS & 6059 & .2663 & .1177 & .2244 & 1.0000 & & \\
\hline COS Working Rel. w/Congress & .5393 & 6136 & -.0194 & .1907 & .4023 & 1.0000 & \\
\hline COS Administrator Role & .5241 & .2856 & -.0173 & .4347 & .3854 & .2969 & 1.0000 \\
\hline COS Management Style & .3785 & .2502 & .0216 & .4447 & .2191 & .1280 & .4769 \\
\hline POTUS Management Style & -.0978 & -.0649 & .1047 & -.2824 & .0017 & -.0088 & -.1388 \\
\hline COS Accessibility & .1815 & .1283 & .0462 & .1426 & .1863 & .1970 & .2199 \\
\hline POTUS Accessibility & -.0034 & -.0300 & .0762 & .0055 & .0533 & .0516 & .0319 \\
\hline COS Visibility & .5460 & .4361 & .0245 & .3034 & .2763 & .3920 & .2927 \\
\hline COS Guardianship & .5564 & .4234 & .0251 & .3308 & .3963 & .3384 & .4649 \\
\hline COS Reality-Tester & .6525 & .5476 & .0265 & .2955 & .5275 & .6191 & .4414 \\
\hline
\end{tabular}

*Continued below on the next page. 
This is an author-produced, peer-reviewed version of this article. The final, definitive version of this document can be found online at Public Administration, published by Wiley-Blackwell. Copyright restrictions may apply. doi: 10.1111/padm.12097

Table A2 Pair-Wise Correlations between all Main Variables (Continued)

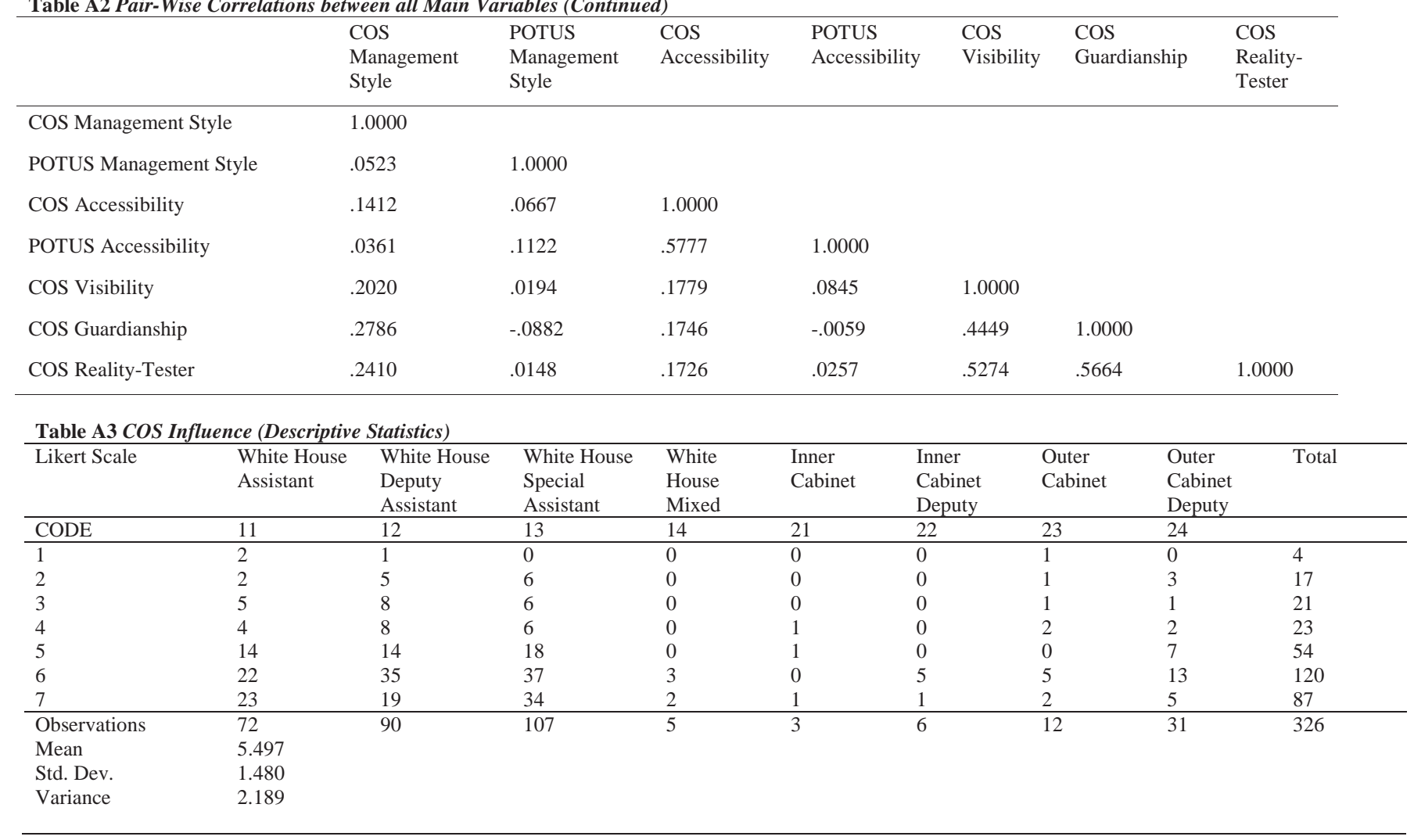


This is an author-produced, peer-reviewed version of this article. The final, definitive version of this document can be found online at Public Administration, published by Wiley-Blackwell. Copyright restrictions may apply. doi: 10.1111/padm.12097

Table A4 COS Experience (Descriptive Statistics)

\begin{tabular}{|c|c|c|c|c|c|c|c|c|c|}
\hline Likert Scale & $\begin{array}{l}\text { White House } \\
\text { Assistant }\end{array}$ & $\begin{array}{l}\text { White House } \\
\text { Deputy } \\
\text { Assistant }\end{array}$ & $\begin{array}{l}\text { White House } \\
\text { Special } \\
\text { Assistant }\end{array}$ & $\begin{array}{l}\text { White } \\
\text { House } \\
\text { Mixed }\end{array}$ & $\begin{array}{l}\text { Inner } \\
\text { Cabinet }\end{array}$ & $\begin{array}{l}\text { Inner } \\
\text { Cabinet } \\
\text { Deputy }\end{array}$ & $\begin{array}{l}\text { Outer } \\
\text { Cabinet }\end{array}$ & $\begin{array}{l}\text { Outer } \\
\text { Cabinet } \\
\text { Deputy }\end{array}$ & Total \\
\hline CODE & 11 & 12 & 13 & 14 & 21 & 22 & 23 & 24 & \\
\hline 1 & 3 & 4 & 2 & 0 & 0 & 0 & 0 & 1 & 10 \\
\hline 2 & 6 & 9 & 11 & 0 & 0 & 0 & 2 & 2 & 30 \\
\hline 3 & 5 & 5 & 7 & 1 & 0 & 0 & 1 & 3 & 22 \\
\hline 4 & 4 & 12 & 8 & 1 & 0 & 0 & 1 & 2 & 28 \\
\hline 5 & 11 & 7 & 11 & 0 & 0 & 3 & 1 & 4 & 37 \\
\hline 6 & 13 & 13 & 12 & 0 & 2 & 0 & 1 & 8 & 49 \\
\hline 7 & 31 & 42 & 57 & 3 & 1 & 3 & 6 & 11 & 154 \\
\hline Observations & 73 & 92 & 108 & 5 & 3 & 6 & 12 & 31 & 330 \\
\hline Mean & 5.470 & & & & & & & & \\
\hline Std. Dev. & 1.860 & & & & & & & & \\
\hline Variance & 3.460 & & & & & & & & \\
\hline
\end{tabular}

Table A5 POTUS Experience (Descriptive Statistics)

\begin{tabular}{|c|c|c|c|c|c|c|c|c|c|}
\hline Likert Scale & $\begin{array}{l}\text { White House } \\
\text { Assistant }\end{array}$ & $\begin{array}{l}\text { White House } \\
\text { Deputy } \\
\text { Assistant }\end{array}$ & $\begin{array}{l}\text { White House } \\
\text { Special } \\
\text { Assistant }\end{array}$ & $\begin{array}{l}\text { White } \\
\text { House } \\
\text { Mixed }\end{array}$ & $\begin{array}{l}\text { Inner } \\
\text { Cabinet }\end{array}$ & $\begin{array}{l}\text { Inner } \\
\text { Cabinet } \\
\text { Deputy }\end{array}$ & $\begin{array}{l}\text { Outer } \\
\text { Cabinet }\end{array}$ & $\begin{array}{l}\text { Outer } \\
\text { Cabinet } \\
\text { Deputy }\end{array}$ & Total \\
\hline CODE & 11 & 12 & 13 & 14 & 21 & 22 & 23 & 24 & \\
\hline 1 & 0 & 0 & 0 & 0 & 0 & 0 & 0 & 0 & 0 \\
\hline 2 & 0 & 0 & 0 & 0 & 0 & 0 & 0 & 0 & 0 \\
\hline 3 & 0 & 1 & 0 & 0 & 0 & 0 & 1 & 0 & 2 \\
\hline 4 & 1 & 2 & 1 & 0 & 0 & 0 & 0 & 0 & 4 \\
\hline 5 & 3 & 3 & 5 & 1 & 0 & 1 & 1 & 2 & 16 \\
\hline 6 & 16 & 13 & 13 & 0 & 1 & 3 & 0 & 9 & 55 \\
\hline 7 & 55 & 73 & 90 & 4 & 2 & 3 & 10 & 20 & 257 \\
\hline Observations & 75 & 92 & 109 & 5 & 3 & 7 & 12 & 31 & 334 \\
\hline Mean & 6.680 & & & & & & & & \\
\hline Std. Dev. & .677 & & & & & & & & \\
\hline Variance & .459 & & & & & & & & \\
\hline
\end{tabular}


This is an author-produced, peer-reviewed version of this article. The final, definitive version of this document can be found online at Public Administration, published by Wiley-Blackwell. Copyright restrictions may apply. doi: 10.1111/padm.12097

Table A6 White House Organization (Descriptive Statistics)

\begin{tabular}{|c|c|c|c|c|c|c|c|c|c|}
\hline Likert Scale & $\begin{array}{l}\text { White House } \\
\text { Assistant }\end{array}$ & $\begin{array}{l}\text { White House } \\
\text { Deputy } \\
\text { Assistant }\end{array}$ & $\begin{array}{l}\text { White House } \\
\text { Special } \\
\text { Assistant }\end{array}$ & $\begin{array}{l}\text { White } \\
\text { House } \\
\text { Mixed }\end{array}$ & $\begin{array}{l}\text { Inner } \\
\text { Cabinet }\end{array}$ & $\begin{array}{l}\text { Inner } \\
\text { Cabinet } \\
\text { Deputy }\end{array}$ & $\begin{array}{l}\text { Outer } \\
\text { Cabinet }\end{array}$ & $\begin{array}{l}\text { Outer } \\
\text { Cabinet } \\
\text { Deputy }\end{array}$ & Total \\
\hline CODE & 11 & 12 & 13 & 14 & 21 & 22 & 23 & 24 & \\
\hline 1 & 1 & 2 & 1 & 0 & 0 & 0 & 0 & 1 & 5 \\
\hline 2 & 5 & 4 & 9 & 0 & 0 & 2 & 0 & 1 & 21 \\
\hline 3 & 3 & 8 & 6 & 0 & 0 & 0 & 2 & 1 & 20 \\
\hline 4 & 9 & 15 & 10 & 0 & 0 & 0 & 2 & 10 & 46 \\
\hline 5 & 17 & 20 & 26 & 0 & 1 & 1 & 2 & 3 & 70 \\
\hline 6 & 28 & 23 & 26 & 2 & 2 & 2 & 6 & 9 & 98 \\
\hline 7 & 12 & 19 & 30 & 3 & 0 & 1 & 0 & 6 & 71 \\
\hline Observations & 75 & 91 & 108 & 5 & 3 & 6 & 12 & 31 & 331 \\
\hline Mean & 5.215 & & & & & & & & \\
\hline Std. Dev. & 1.519 & & & & & & & & \\
\hline Variance & 2.308 & & & & & & & & \\
\hline
\end{tabular}

Table A7 COS Working Relationship w/POTUS (Descriptive Statistics)

\begin{tabular}{|c|c|c|c|c|c|c|c|c|c|}
\hline Likert Scale & $\begin{array}{l}\text { White House } \\
\text { Assistant }\end{array}$ & $\begin{array}{l}\text { White House } \\
\text { Deputy } \\
\text { Assistant }\end{array}$ & $\begin{array}{l}\text { White House } \\
\text { Special } \\
\text { Assistant }\end{array}$ & $\begin{array}{l}\text { White } \\
\text { House } \\
\text { Mixed }\end{array}$ & $\begin{array}{l}\text { Inner } \\
\text { Cabinet }\end{array}$ & $\begin{array}{l}\text { Inner } \\
\text { Cabinet } \\
\text { Deputy }\end{array}$ & $\begin{array}{l}\text { Outer } \\
\text { Cabinet }\end{array}$ & $\begin{array}{l}\text { Outer } \\
\text { Cabinet } \\
\text { Deputy }\end{array}$ & Total \\
\hline CODE & 11 & 12 & 13 & 14 & 21 & 22 & 23 & 24 & \\
\hline 1 & 0 & 0 & 0 & 0 & 0 & 0 & 0 & 0 & 0 \\
\hline 2 & 1 & 1 & 2 & 0 & 0 & 0 & 0 & 0 & 4 \\
\hline 3 & 1 & 0 & 1 & 0 & 0 & 0 & 1 & 1 & 4 \\
\hline 4 & 2 & 7 & 6 & 0 & 0 & 0 & 1 & 1 & 17 \\
\hline 5 & 14 & 17 & 18 & 1 & 1 & 0 & 3 & 7 & 61 \\
\hline 6 & 28 & 33 & 36 & 1 & 1 & 2 & 2 & 9 & 112 \\
\hline 7 & 27 & 33 & 44 & 3 & 1 & 2 & 5 & 12 & 127 \\
\hline Observations & 74 & 91 & 107 & 5 & 3 & 4 & 12 & 30 & 325 \\
\hline Mean & 6.012 & & & & & & & & \\
\hline Std. Dev. & 1.048 & & & & & & & & \\
\hline Variance & 1.099 & & & & & & & & \\
\hline
\end{tabular}


This is an author-produced, peer-reviewed version of this article. The final, definitive version of this document can be found online at Public Administration, published by Wiley-Blackwell. Copyright restrictions may apply. doi: 10.1111/padm.12097

Table A8 COS Working Relationship w/Congress (Descriptive Statistics)

\begin{tabular}{|c|c|c|c|c|c|c|c|c|c|}
\hline Likert Scale & $\begin{array}{l}\text { White House } \\
\text { Assistant }\end{array}$ & $\begin{array}{l}\text { White House } \\
\text { Deputy } \\
\text { Assistant }\end{array}$ & $\begin{array}{l}\text { White House } \\
\text { Special } \\
\text { Assistant }\end{array}$ & $\begin{array}{l}\text { White } \\
\text { House } \\
\text { Mixed }\end{array}$ & $\begin{array}{l}\text { Inner } \\
\text { Cabinet }\end{array}$ & $\begin{array}{l}\text { Inner } \\
\text { Cabinet } \\
\text { Deputy }\end{array}$ & $\begin{array}{l}\text { Outer } \\
\text { Cabinet }\end{array}$ & $\begin{array}{l}\text { Outer } \\
\text { Cabinet } \\
\text { Deputy }\end{array}$ & Total \\
\hline CODE & 11 & 12 & 13 & 14 & 21 & 22 & 23 & 24 & \\
\hline 1 & 2 & 1 & 1 & 0 & 0 & 0 & 0 & 1 & 5 \\
\hline 2 & 6 & 5 & 10 & 0 & 0 & 0 & 1 & 1 & 23 \\
\hline 3 & 4 & 12 & 13 & 0 & 1 & 0 & 1 & 4 & 35 \\
\hline 4 & 11 & 11 & 10 & 1 & 0 & 1 & 4 & 7 & 45 \\
\hline 5 & 10 & 18 & 15 & 1 & 1 & 1 & 2 & 4 & 52 \\
\hline 6 & 18 & 18 & 30 & 0 & 1 & 0 & 1 & 10 & 78 \\
\hline 7 & 22 & 27 & 27 & 2 & 0 & 2 & 3 & 3 & 86 \\
\hline Observations & 73 & 92 & 106 & 4 & 3 & 4 & 12 & 30 & 324 \\
\hline Mean & 5.142 & & & & & & & & \\
\hline Std. Dev. & 1.658 & & & & & & & & \\
\hline Variance & 2.748 & & & & & & & & \\
\hline
\end{tabular}

Table A9 COS Administrator Role (Descriptive Statistics)

\begin{tabular}{|c|c|c|c|c|c|c|c|c|c|}
\hline Likert Scale & $\begin{array}{l}\text { White House } \\
\text { Assistant }\end{array}$ & $\begin{array}{l}\text { White House } \\
\text { Deputy Assistant }\end{array}$ & $\begin{array}{l}\text { White House } \\
\text { Special Assistant }\end{array}$ & $\begin{array}{l}\text { White House } \\
\text { Mixed }\end{array}$ & $\begin{array}{l}\text { Inner } \\
\text { Cabinet }\end{array}$ & $\begin{array}{l}\text { Inner Cabinet } \\
\text { Deputy }\end{array}$ & $\begin{array}{l}\text { Outer } \\
\text { Cabinet }\end{array}$ & $\begin{array}{l}\text { Outer Cabinet } \\
\text { Deputy }\end{array}$ & Total \\
\hline CODE & 11 & 12 & 13 & 14 & 21 & 22 & 23 & 24 & \\
\hline 1 & 0 & 0 & 0 & 0 & 0 & 0 & 0 & 0 & 0 \\
\hline 2 & 2 & 3 & 3 & 0 & 0 & 0 & 0 & 1 & 9 \\
\hline 3 & 1 & 6 & 2 & 0 & 0 & 0 & 0 & 3 & 12 \\
\hline 4 & 6 & 4 & 9 & 0 & 0 & 0 & 2 & 0 & 21 \\
\hline 5 & 17 & 21 & 25 & 1 & 0 & 0 & 1 & 9 & 74 \\
\hline 6 & 23 & 32 & 32 & 1 & 2 & 4 & 4 & 10 & 108 \\
\hline 7 & 25 & 24 & 31 & 3 & 1 & 1 & 3 & 7 & 95 \\
\hline Observations & 74 & 90 & 102 & 5 & 3 & 5 & 10 & 30 & 319 \\
\hline Mean & 5.708 & & & & & & & & \\
\hline Std. Dev. & 1.226 & & & & & & & & \\
\hline Variance & 1.503 & & & & & & & & \\
\hline
\end{tabular}


This is an author-produced, peer-reviewed version of this article. The final, definitive version of this document can be found online at Public Administration, published by Wiley-Blackwell. Copyright restrictions may apply. doi: 10.1111/padm.12097

Table A10 COS Management Style (Descriptive Statistics)

\begin{tabular}{|c|c|c|c|c|c|c|c|c|c|}
\hline Likert Scale & $\begin{array}{l}\text { White House } \\
\text { Assistant }\end{array}$ & $\begin{array}{l}\text { White House } \\
\text { Deputy } \\
\text { Assistant }\end{array}$ & $\begin{array}{l}\text { White House } \\
\text { Special } \\
\text { Assistant }\end{array}$ & $\begin{array}{l}\text { White } \\
\text { House } \\
\text { Mixed }\end{array}$ & $\begin{array}{l}\text { Inner } \\
\text { Cabinet }\end{array}$ & $\begin{array}{l}\text { Inner } \\
\text { Cabinet } \\
\text { Deputy }\end{array}$ & $\begin{array}{l}\text { Outer } \\
\text { Cabinet }\end{array}$ & $\begin{array}{l}\text { Outer } \\
\text { Cabinet } \\
\text { Deputy }\end{array}$ & Total \\
\hline CODE & 11 & 12 & 13 & 14 & 21 & 22 & 23 & 24 & \\
\hline 1 & 2 & 3 & 1 & 0 & 0 & 0 & 0 & 0 & 6 \\
\hline 2 & 4 & 5 & 4 & 1 & 0 & 0 & 1 & 1 & 16 \\
\hline 3 & 7 & 13 & 10 & 0 & 0 & 0 & 1 & 2 & 33 \\
\hline 4 & 6 & 7 & 14 & 0 & 0 & 0 & 2 & 7 & 36 \\
\hline 5 & 21 & 20 & 22 & 0 & 1 & 2 & 1 & 8 & 75 \\
\hline 6 & 17 & 27 & 36 & 1 & 0 & 3 & 5 & 8 & 97 \\
\hline 7 & 15 & 14 & 20 & 3 & 1 & 1 & 1 & 5 & 60 \\
\hline Observations & 72 & 89 & 107 & 5 & 2 & 6 & 11 & 31 & 323 \\
\hline Mean & 3.095 & & & & & & & & \\
\hline Std. Dev. & 1.570 & & & & & & & & \\
\hline Variance & 2.466 & & & & & & & & \\
\hline
\end{tabular}

Table A11 POTUS Management Style (Descriptive Statistics)

\begin{tabular}{|c|c|c|c|c|c|c|c|c|c|}
\hline Likert Scale & $\begin{array}{l}\text { White House } \\
\text { Assistant }\end{array}$ & $\begin{array}{l}\text { White House } \\
\text { Deputy } \\
\text { Assistant }\end{array}$ & $\begin{array}{l}\text { White House } \\
\text { Special } \\
\text { Assistant }\end{array}$ & $\begin{array}{l}\text { White } \\
\text { House } \\
\text { Mixed }\end{array}$ & $\begin{array}{l}\text { Inner } \\
\text { Cabinet }\end{array}$ & $\begin{array}{l}\text { Inner } \\
\text { Cabinet } \\
\text { Deputy }\end{array}$ & $\begin{array}{l}\text { Outer } \\
\text { Cabinet }\end{array}$ & $\begin{array}{l}\text { Outer } \\
\text { Cabinet } \\
\text { Deputy }\end{array}$ & Total \\
\hline CODE & 11 & 12 & 13 & 14 & 21 & 22 & 23 & 24 & \\
\hline 1 & 11 & 17 & 15 & 1 & 0 & 1 & 1 & 1 & 47 \\
\hline 2 & 21 & 25 & 33 & 0 & 1 & 2 & 2 & 11 & 95 \\
\hline 3 & 17 & 15 & 25 & 1 & 1 & 1 & 3 & 8 & 71 \\
\hline 4 & 11 & 9 & 15 & 2 & 0 & 1 & 4 & 4 & 46 \\
\hline 5 & 8 & 15 & 10 & 0 & 0 & 2 & 1 & 2 & 38 \\
\hline 6 & 5 & 8 & 6 & 1 & 0 & 0 & 0 & 2 & 22 \\
\hline 7 & 1 & 1 & 3 & 0 & 0 & 0 & 0 & 3 & 8 \\
\hline Observations & 74 & 90 & 107 & 5 & 2 & 7 & 11 & 31 & 327 \\
\hline Mean & 3.095 & & & & & & & & \\
\hline Std. Dev. & 1.570 & & & & & & & & \\
\hline Variance & 2.466 & & & & & & & & \\
\hline
\end{tabular}


This is an author-produced, peer-reviewed version of this article. The final, definitive version of this document can be found online at Public Administration, published by Wiley-Blackwell. Copyright restrictions may apply. doi: 10.1111/padm.12097

Table A12 COS Accessibility (Descriptive Statistics)

\begin{tabular}{|c|c|c|c|c|c|c|c|c|c|}
\hline Likert Scale & $\begin{array}{l}\text { White House } \\
\text { Assistant }\end{array}$ & $\begin{array}{l}\text { White House } \\
\text { Deputy } \\
\text { Assistant }\end{array}$ & $\begin{array}{l}\text { White House } \\
\text { Special } \\
\text { Assistant }\end{array}$ & $\begin{array}{l}\text { White } \\
\text { House } \\
\text { Mixed }\end{array}$ & $\begin{array}{l}\text { Inner } \\
\text { Cabinet }\end{array}$ & $\begin{array}{l}\text { Inner } \\
\text { Cabinet } \\
\text { Deputy }\end{array}$ & $\begin{array}{l}\text { Outer } \\
\text { Cabinet }\end{array}$ & $\begin{array}{l}\text { Outer } \\
\text { Cabinet } \\
\text { Deputy }\end{array}$ & Total \\
\hline CODE & 11 & 12 & 13 & 14 & 21 & 22 & 23 & 24 & \\
\hline 1 & 1 & 2 & 4 & 0 & 0 & 1 & 1 & 4 & 13 \\
\hline 2 & 0 & 3 & 13 & 0 & 0 & 0 & 0 & 1 & 17 \\
\hline 3 & 0 & 5 & 11 & 0 & 1 & 0 & 0 & 1 & 18 \\
\hline 4 & 2 & 10 & 23 & 0 & 0 & 2 & 0 & 11 & 48 \\
\hline 5 & 7 & 16 & 13 & 1 & 0 & 2 & 2 & 4 & 45 \\
\hline 6 & 20 & 25 & 23 & 2 & 0 & 0 & 5 & 6 & 81 \\
\hline 7 & 46 & 30 & 21 & 2 & 2 & 2 & 4 & 4 & 111 \\
\hline Observations & 76 & 91 & 108 & 5 & 3 & 7 & 12 & 31 & 333 \\
\hline Mean & 4.318 & & & & & & & & \\
\hline Std. Dev. & 1.916 & & & & & & & & \\
\hline Variance & 3.672 & & & & & & & & \\
\hline
\end{tabular}

Table A13 POTUS Accessibility (Descriptive Statistics)

\begin{tabular}{|c|c|c|c|c|c|c|c|c|c|}
\hline Likert Scale & $\begin{array}{l}\text { White House } \\
\text { Assistant }\end{array}$ & $\begin{array}{l}\text { White House } \\
\text { Deputy } \\
\text { Assistant }\end{array}$ & $\begin{array}{l}\text { White House } \\
\text { Special } \\
\text { Assistant }\end{array}$ & $\begin{array}{l}\text { White } \\
\text { House } \\
\text { Mixed }\end{array}$ & $\begin{array}{l}\text { Inner } \\
\text { Cabinet }\end{array}$ & $\begin{array}{l}\text { Inner } \\
\text { Cabinet } \\
\text { Deputy }\end{array}$ & $\begin{array}{l}\text { Outer } \\
\text { Cabinet }\end{array}$ & $\begin{array}{l}\text { Outer } \\
\text { Cabinet } \\
\text { Deputy }\end{array}$ & Total \\
\hline CODE & 11 & 12 & 13 & 14 & 21 & 22 & 23 & 24 & \\
\hline 1 & 0 & 3 & 13 & 0 & 0 & 1 & 1 & 2 & 20 \\
\hline 2 & 2 & 13 & 35 & 1 & 0 & 2 & 0 & 14 & 67 \\
\hline 3 & 7 & 8 & 11 & 0 & 0 & 2 & 0 & 4 & 32 \\
\hline 4 & 5 & 18 & 10 & 0 & 0 & 0 & 1 & 5 & 39 \\
\hline 5 & 20 & 22 & 19 & 1 & 2 & 2 & 5 & 2 & 73 \\
\hline 6 & 18 & 12 & 9 & 2 & 0 & 0 & 3 & 0 & 44 \\
\hline 7 & 23 & 16 & 11 & 1 & 1 & 0 & 2 & 4 & 58 \\
\hline Observations & 75 & 92 & 108 & 5 & 3 & 7 & 12 & 31 & 333 \\
\hline Mean & 4.327 & & & & & & & & \\
\hline Std. Dev. & 1.913 & & & & & & & & \\
\hline Variance & 3.661 & & & & & & & & \\
\hline
\end{tabular}


This is an author-produced, peer-reviewed version of this article. The final, definitive version of this document can be found online at Public Administration, published by Wiley-Blackwell. Copyright restrictions may apply. doi: 10.1111/padm.12097

Table A14 COS Visibility (Descriptive Statistics)

\begin{tabular}{|c|c|c|c|c|c|c|c|c|c|}
\hline Likert Scale & $\begin{array}{l}\text { White House } \\
\text { Assistant }\end{array}$ & $\begin{array}{l}\text { White House } \\
\text { Deputy } \\
\text { Assistant }\end{array}$ & $\begin{array}{l}\text { White House } \\
\text { Special } \\
\text { Assistant }\end{array}$ & $\begin{array}{l}\text { White } \\
\text { House } \\
\text { Mixed }\end{array}$ & $\begin{array}{l}\text { Inner } \\
\text { Cabinet }\end{array}$ & $\begin{array}{l}\text { Inner } \\
\text { Cabinet } \\
\text { Deputy }\end{array}$ & $\begin{array}{l}\text { Outer } \\
\text { Cabinet }\end{array}$ & $\begin{array}{l}\text { Outer } \\
\text { Cabinet } \\
\text { Deputy }\end{array}$ & Total \\
\hline CODE & 11 & 12 & 13 & 14 & 21 & 22 & 23 & 24 & \\
\hline 1 & 3 & 2 & 0 & 0 & 0 & 0 & 0 & 0 & 5 \\
\hline 2 & 3 & 6 & 11 & 1 & 0 & 1 & 2 & 2 & 26 \\
\hline 3 & 13 & 12 & 15 & 0 & 1 & 1 & 2 & 4 & 48 \\
\hline 4 & 12 & 21 & 17 & 0 & 1 & 1 & 1 & 7 & 60 \\
\hline 5 & 8 & 18 & 20 & 0 & 1 & 0 & 1 & 10 & 58 \\
\hline 6 & 19 & 20 & 24 & 2 & 0 & 3 & 3 & 7 & 78 \\
\hline 7 & 14 & 12 & 19 & 2 & 0 & 0 & 3 & 1 & 51 \\
\hline Observations & 72 & 91 & 106 & 5 & 3 & 6 & 12 & 31 & 326 \\
\hline Mean & 4.773 & & & & & & & & \\
\hline Std. Dev. & 1.599 & & & & & & & & \\
\hline Variance & 2.558 & & & & & & & & \\
\hline
\end{tabular}

Table A15 COS Guardianship (Descriptive Statistics)

\begin{tabular}{|c|c|c|c|c|c|c|c|c|c|}
\hline Likert Scale & $\begin{array}{l}\text { White House } \\
\text { Assistant }\end{array}$ & $\begin{array}{l}\text { White House } \\
\text { Deputy } \\
\text { Assistant }\end{array}$ & $\begin{array}{l}\text { White House } \\
\text { Special } \\
\text { Assistant }\end{array}$ & $\begin{array}{l}\text { White } \\
\text { House } \\
\text { Mixed }\end{array}$ & $\begin{array}{l}\text { Inner } \\
\text { Cabinet }\end{array}$ & $\begin{array}{l}\text { Inner } \\
\text { Cabinet } \\
\text { Deputy }\end{array}$ & $\begin{array}{l}\text { Outer } \\
\text { Cabinet }\end{array}$ & $\begin{array}{l}\text { Outer } \\
\text { Cabinet } \\
\text { Deputy }\end{array}$ & Total \\
\hline CODE & 11 & 12 & 13 & 14 & 21 & 22 & 23 & 24 & \\
\hline 1 & 1 & 0 & 2 & 0 & 0 & 0 & 0 & 0 & 3 \\
\hline 2 & 3 & 6 & 7 & 0 & 0 & 0 & 3 & 1 & 20 \\
\hline 3 & 3 & 4 & 6 & 0 & 0 & 0 & 1 & 2 & 16 \\
\hline 4 & 10 & 18 & 10 & 1 & 0 & 1 & 1 & 4 & 45 \\
\hline 5 & 22 & 24 & 25 & 1 & 0 & 2 & 1 & 5 & 80 \\
\hline 6 & 22 & 22 & 31 & 2 & 3 & 2 & 4 & 14 & 100 \\
\hline 7 & 11 & 16 & 23 & 1 & 0 & 1 & 2 & 4 & 58 \\
\hline Observations & 72 & 90 & 104 & 5 & 3 & 6 & 12 & 30 & 322 \\
\hline Mean & 5.208 & & & & & & & & \\
\hline Std. Dev. & 1.429 & & & & & & & & \\
\hline Variance & 2.041 & & & & & & & & \\
\hline
\end{tabular}


This is an author-produced, peer-reviewed version of this article. The final, definitive version of this document can be found online at Public Administration, published by Wiley-Blackwell. Copyright restrictions may apply. doi: 10.1111/padm.12097

Table A16 COS Reality-Tester (Descriptive Statistics)

\begin{tabular}{|c|c|c|c|c|c|c|c|c|c|}
\hline Likert Scale & $\begin{array}{l}\text { White House } \\
\text { Assistant }\end{array}$ & $\begin{array}{l}\text { White House } \\
\text { Deputy } \\
\text { Assistant }\end{array}$ & $\begin{array}{l}\text { White House } \\
\text { Special } \\
\text { Assistant }\end{array}$ & $\begin{array}{l}\text { White } \\
\text { House } \\
\text { Mixed }\end{array}$ & $\begin{array}{l}\text { Inner } \\
\text { Cabinet }\end{array}$ & $\begin{array}{l}\text { Inner } \\
\text { Cabinet } \\
\text { Deputy }\end{array}$ & $\begin{array}{l}\text { Outer } \\
\text { Cabinet }\end{array}$ & $\begin{array}{l}\text { Outer } \\
\text { Cabinet } \\
\text { Deputy }\end{array}$ & Total \\
\hline CODE & 11 & 12 & 13 & 14 & 21 & 22 & 23 & 24 & \\
\hline 1 & 3 & 2 & 1 & 0 & 0 & 0 & 1 & 0 & 7 \\
\hline 2 & 3 & 6 & 8 & 0 & 0 & 0 & 2 & 2 & 21 \\
\hline 3 & 2 & 8 & 7 & 0 & 0 & 0 & 0 & 2 & 19 \\
\hline 4 & 11 & 19 & 8 & 0 & 0 & 0 & 2 & 5 & 41 \\
\hline 5 & 17 & 18 & 19 & 0 & 2 & 0 & 0 & 6 & 62 \\
\hline 6 & 17 & 27 & 29 & 3 & 1 & 3 & 5 & 9 & 94 \\
\hline 7 & 18 & 11 & 28 & 2 & 0 & 1 & 1 & 5 & 66 \\
\hline Observations & 71 & 87 & 100 & 5 & 3 & 4 & 11 & 29 & 310 \\
\hline Mean & 5.181 & & & & & & & & \\
\hline Std. Dev. & 1.574 & & & & & & & & \\
\hline Variance & 2.479 & & & & & & & & \\
\hline
\end{tabular}


This is an author-produced, peer-reviewed version of this article. The final, definitive version of this document can be found online at Public Administration, published by Wiley-Blackwell. Copyright restrictions may apply. doi: 10.1111/padm.12097

Table A17 Presidential and Chief of Staff Experience: Comparing Objective and Subjective Measures (1981-2001)

\begin{tabular}{lll}
\hline President & Subjective (Means)* & Objective (Years)** $^{*}$ \\
\hline Ronald Reagan & 6.439 & 15 \\
George H.W. Bush & 6.76 & 23 \\
Bill Clinton & 6.839 & 20 \\
\hline Chief of Staff & & 7 \\
\hline James A. Baker III & 6.474 & 4 \\
Donald T. Regan & 3.094 & 21 \\
Howard H. Baker, Jr. & 7 & 13 \\
Kenneth M. Duberstein & 5.818 & 11 \\
John H. Sununu & 6.125 & 16 \\
Samuel K. Skinner & 4.529 & 9 \\
Thomas F. McLarty III & 2.581 & 25 \\
Leon E. Panetta & 6.78 & 4 \\
Erskine B. Bowles & 4.059 & 11 \\
John D. Podesta & 6.628 & \\
*Subjective measures are based on the means from our 7-point Likert scale survey scores (see the full \\
descriptive statistics in Tables A19-A33). \\
**Objective measures are based on years of observed experience (see Table A18).
\end{tabular}


This is an author-produced, peer-reviewed version of this article. The final, definitive version of this document can be found online at Public

Administration, published by Wiley-Blackwell. Copyright restrictions may apply. doi: 10.1111/padm.12097

Table A18 Objective Presidential and Chief of Staff Political Experience (Years)*

\begin{tabular}{|c|c|}
\hline \multicolumn{2}{|l|}{ President } \\
\hline Ronald Reagan & $\begin{array}{l}\text { Political launch with Goldwater campaign (1964); Governor of } \\
\text { California campaign (1966); Governor of California (1967-75); } \\
\text { Presidential candidate (1976); Political Activism with the Ronald Reagan } \\
\text { Radio Commentary series and Citizens for the Republic political action } \\
\text { committee (1976-79); Presidential candidate (1979-80) }\end{array}$ \\
\hline George H.W. Bush & $\begin{array}{l}\text { Chairman of the Republican Party for Harris County, Texas (1964); U.S. } \\
\text { Senate candidate (1964); U.S. House of Representatives candidate } \\
\text { (1966); Member, U.S. House of Representatives (TX) (1967-71); U.S. } \\
\text { Senate candidate (1970); U.S. Ambassador to the U.N. (1971-73); } \\
\text { Chairman of the Republican National Committee (1973-74); Chief of the } \\
\text { Liaison Office to the People’s Republic of China (1974-75); Director of } \\
\text { Central Intelligence (1976-77); Presidential candidate (1980); Vice } \\
\text { President of the U.S. (1981-89) }\end{array}$ \\
\hline Bill Clinton & $\begin{array}{l}\text { Assistant to Senator Fulbright (1967); Coordinator for McGovern- } \\
\text { Shriver ’72 (1971); U.S. House of Representatives candidate (1974); } \\
\text { Attorney General of Arkansas candidate (1976); Attorney General of } \\
\text { Arkansas (1977-79); Governor of Arkansas candidate (1978); Governor } \\
\text { of Arkansas (1979-81); Governor of Arkansas candidate (1980); } \\
\text { Governor of Arkansas candidate (1982); Governor of Arkansas (1983- } \\
\text { 1992); Presidential candidate (1991) }\end{array}$ \\
\hline \multicolumn{2}{|l|}{ Chief of Staff } \\
\hline James A. Baker III & $\begin{array}{l}\text { U.S. Congressional candidate (1969); Chairman, George H.W. Bush } \\
\text { Senate campaign (1970); Finance Chairman of the Republican Party } \\
\text { (1971); Gulf Coast Regional Chairman, Nixon Presidential Campaign } \\
\text { (1972); Undersecretary of Commerce, President Ford (1975); Chairman, } \\
\text { Gerald Ford election campaign (1976); Attorney General of Texas } \\
\text { candidate (1978) }\end{array}$ \\
\hline Donald T. Regan & U.S. Treasury Secretary (1981-85) \\
\hline Howard H. Baker, Jr. & $\begin{array}{l}\text { U.S. Senate camp (1964); U.S. Senate candidate (1965); U.S. Senator } \\
\text { (1966-84); Presidential candidate (1980) }\end{array}$ \\
\hline Kenneth M. Duberstein & $\begin{array}{l}\text { Legislative Assistant to Senator Jacob K. Javits (1966); Director, } \\
\text { Congressional and Intergovernmental Affairs, U.S. General Services } \\
\text { Administration (1970-76); Deputy Under Secretary, Department of Labor } \\
\text { (1976-77); Assistant to the President, Legislative Affairs (1981-83); } \\
\text { Member, Congressional Liaison Team for Reagan-Bush ’84 (1984) }\end{array}$ \\
\hline John H. Sununu & $\begin{array}{l}\text { New Hampshire House of Representatives campaign (1972); New } \\
\text { Hampshire House of Representatives (1973-75); Governor of New } \\
\text { Hampshire campaign (1982); Governor of New Hampshire (1983-87); } \\
\text { Chairman, National Governor’s Association (1978-88) }\end{array}$ \\
\hline Samuel K. Skinner & $\begin{array}{l}\text { U.S. Attorney, Northern District of Illinois (1968-75); U.S. Attorney } \\
\text { (1975-77); Vice Chairman, President Reagan’s Commission on } \\
\text { Organized Crime (1984-88); U.S. Secretary of Transportation (1989-91) }\end{array}$ \\
\hline Thomas F. McLarty III & $\begin{array}{l}\text { Arkansas House of Representatives candidate (1970); Arkansas House of } \\
\text { Representatives (1971-73); Treasurer, gubernatorial election for David } \\
\text { Pryor (1974); Chairman, Arkansas State Democratic Party (1974-76); } \\
\text { Member, Democratic National Committee (1976-77); Treasurer, } \\
\text { gubernatorial election for Bill Clinton (1980) }\end{array}$ \\
\hline Leon E. Panetta & $\begin{array}{l}\text { Legislative Assistant to Senator Thomas Kuchel (1966-69); Assistant to } \\
\text { the Secretary of the U.S. Department of Health, Education, and Welfare } \\
\text { (1969-70); Assistant to John Lindsay, New York Mayor (1970-71); U.S. } \\
\text { House of Representatives candidate (1976); Member, U.S. House of } \\
\text { Representatives (CA) (1977-93); Director, Office of Management and }\end{array}$ \\
\hline
\end{tabular}


This is an author-produced, peer-reviewed version of this article. The final, definitive version of this document can be found online at Public

Administration, published by Wiley-Blackwell. Copyright restrictions may apply. doi: 10.1111/padm.12097

Erskine B. Bowles

John D. Podesta
Budget (OMB) (1993-94)

Gubernatorial campaign for Hargrove Bowles (father) (1972); Fundraiser for Clinton-Gore '92 (1992); Head of the Small Business Administration (SBA) (1993); White House Deputy Chief of Staff (1994-95)

Counsel on the Majority Staff of the Senate Judiciary Committee and Chief Minority Counsel for two Senate Judiciary Subcommittees (197981); Chief Counsel for the Senate Agricultural Committee (1987-88); Assistant to the President, Staff Secretary, and Senior Policy Advisor (1993-95); Counselor to Senator Thomas Daschle (1995-96); White House Deputy Chief of Staff (1997-98)

\footnotetext{
*Rounded to the nearest year. Years where overlap occurs due to holding more than one position (or activity) at a time are counted as a single year of experience.
} 
Table A19 POTUS Experience (Overall Descriptive

Statistics)

\begin{tabular}{lll}
\hline Likert Scale & Frequency & Percent \\
\hline 1 & 0 & 0 \\
2 & 0 & 0 \\
3 & 2 & .6 \\
4 & 4 & 1.2 \\
5 & 16 & 4.79 \\
6 & 55 & 16.47 \\
7 & 257 & 76.95 \\
\hline Total & 334 & 100 \\
Mean & 6.68 & \\
Std. Dev. & .677 & \\
& & \\
\hline
\end{tabular}

Table A20 COS Experience (Overall Descriptive Statistics)

\begin{tabular}{lll}
\hline Likert Scale & Frequency & Percent \\
\hline 1 & 10 & 3.03 \\
2 & 30 & 9.09 \\
3 & 22 & 6.67 \\
4 & 28 & 8.48 \\
5 & 37 & 11.21 \\
6 & 49 & 14.85 \\
7 & 154 & 46.67 \\
\hline Total & 330 & 100 \\
Mean & 5.47 & \\
Std. Dev. & 1.86 & \\
& & \\
\hline
\end{tabular}

Table A21 Reagan Experience (Descriptive Statistics)

\begin{tabular}{lll}
\hline Likert Scale & Frequency & Percent \\
\hline 1 & 0 & 0 \\
2 & 0 & 0 \\
3 & 1 & .81 \\
4 & 1 & .81 \\
5 & 16 & 13.01 \\
6 & 30 & 24.39 \\
7 & 75 & 60.98 \\
\hline Total & 123 & 100 \\
Mean & 6.439 & \\
Std. Dev. & .811 & \\
& & \\
\hline
\end{tabular}


This is an author-produced, peer-reviewed version of this article. The final, definitive version of this document can be found online at Public Administration, published by Wiley-Blackwell. Copyright restrictions may apply. doi: 10.1111/padm.12097

Table A22 G.W. Bush Experience (Descriptive Statistics)

\begin{tabular}{lll}
\hline Likert Scale & Frequency & Percent \\
\hline 1 & 0 & 0 \\
2 & 0 & 0 \\
3 & 1 & 2 \\
4 & 0 & 0 \\
5 & 0 & 0 \\
6 & 8 & 16 \\
7 & 41 & 82 \\
\hline Total & 50 & 100 \\
Mean & 6.76 & \\
Std. Dev. & .657 & \\
& & \\
\hline
\end{tabular}

Table A23 Clinton Experience (Descriptive Statistics)

\begin{tabular}{lll}
\hline Likert Scale & Frequency & Percent \\
\hline 1 & 0 & 0 \\
2 & 0 & 0 \\
3 & 0 & 0 \\
4 & 3 & 1.86 \\
5 & 0 & 0 \\
6 & 17 & 10.56 \\
7 & 141 & 87.58 \\
\hline Total & 161 & 100 \\
Mean & 6.839 & \\
Std. Dev. & .499 & \\
& & \\
\hline
\end{tabular}

Table A24 J. Baker Experience (Descriptive Statistics)

\begin{tabular}{lll}
\hline Likert Scale & Frequency & Percent \\
\hline 1 & 0 & 0 \\
2 & 1 & 2.63 \\
3 & 0 & 0 \\
4 & 1 & 2.63 \\
5 & 3 & 7.89 \\
6 & 6 & 15.79 \\
7 & 27 & 71.05 \\
\hline Total & 38 & 100 \\
Mean & 6.474 & \\
Std. Dev. & 1.059 & \\
& & \\
\hline
\end{tabular}


This is an author-produced, peer-reviewed version of this article. The final, definitive version of this document can be found online at Public Administration, published by Wiley-Blackwell. Copyright restrictions may apply. doi: 10.1111/padm.12097

Table A25 Regan Experience (Descriptive Statistics)

\begin{tabular}{lll}
\hline Likert Scale & Frequency & Percent \\
\hline 1 & 2 & 6.25 \\
2 & 10 & 31.25 \\
3 & 9 & 28.13 \\
4 & 6 & 18.75 \\
5 & 4 & 12.5 \\
6 & 1 & 3.13 \\
7 & 0 & 0 \\
\hline Total & 32 & 100 \\
Mean & 3.094 & \\
Std. Dev. & 1.254 & \\
& & \\
\hline
\end{tabular}

Table A26 H. Baker Experience (Descriptive Statistics)

\begin{tabular}{lll}
\hline Likert Scale & Frequency & Percent \\
\hline 1 & 0 & 0 \\
2 & 0 & 0 \\
3 & 0 & 0 \\
4 & 0 & 0 \\
5 & 0 & 0 \\
6 & 0 & 0 \\
7 & 31 & 100 \\
\hline Total & 31 & 100 \\
Mean & 7 & \\
Std. Dev. & 0 & \\
& & \\
\hline
\end{tabular}

Table A27 Duberstein Experience (Descriptive Statistics)

\begin{tabular}{lll}
\hline Likert Scale & Frequency & Percent \\
\hline 1 & 0 & 0 \\
2 & 0 & 0 \\
3 & 0 & 0 \\
4 & 2 & 9.09 \\
5 & 7 & 31.82 \\
6 & 6 & 27.27 \\
7 & 7 & 31.82 \\
\hline Total & 22 & 100 \\
Mean & 5.818 & \\
Std. Dev. & 1.006 & \\
& & \\
\hline
\end{tabular}


Table A28 Sununu Experience (Descriptive Statistics)

\begin{tabular}{lll}
\hline Likert Scale & Frequency & Percent \\
\hline 1 & 0 & 0 \\
2 & 0 & 0 \\
3 & 1 & 3.13 \\
4 & 2 & 6.25 \\
5 & 5 & 15.63 \\
6 & 8 & 25 \\
7 & 16 & 50 \\
\hline Total & 32 & 100 \\
Mean & 6.125 & \\
Std. Dev. & 1.1 & \\
& & \\
\hline
\end{tabular}

Table A29 Skinner Experience (Descriptive Statistics)

\begin{tabular}{lll}
\hline Likert Scale & Frequency & Percent \\
\hline 1 & 0 & 0 \\
2 & 2 & 11.76 \\
3 & 0 & 0 \\
4 & 6 & 35.29 \\
5 & 5 & 29.41 \\
6 & 4 & 23.53 \\
7 & 0 & 0 \\
\hline Total & 17 & 100 \\
Mean & 4.529 & \\
Std. Dev. & 1.231 & \\
& & \\
\hline
\end{tabular}

Table A30 McLarty Experience (Descriptive Statistics)

\begin{tabular}{lll}
\hline Likert Scale & Frequency & Percent \\
\hline 1 & 8 & 25.81 \\
2 & 12 & 38.71 \\
3 & 3 & 9.68 \\
4 & 3 & 9.68 \\
5 & 3 & 9.68 \\
6 & 2 & 6.45 \\
7 & 0 & 0 \\
\hline Total & 31 & 100 \\
Mean & 2.581 & \\
Std. Dev. & 1.544 & \\
& & \\
\hline
\end{tabular}


Table A31 Panetta Experience (Descriptive Statistics)

\begin{tabular}{lll}
\hline Likert Scale & Frequency & Percent \\
\hline 1 & 0 & 0 \\
2 & 0 & 0 \\
3 & 0 & 0 \\
4 & 1 & 2 \\
5 & 0 & 0 \\
6 & 8 & 16 \\
7 & 41 & 82 \\
\hline Total & 50 & 100 \\
Mean & 6.78 & \\
Std. Dev. & .545 & \\
& & \\
\hline
\end{tabular}

Table A32 Bowles Experience (Descriptive Statistics)

\begin{tabular}{lll}
\hline Likert Scale & Frequency & Percent \\
\hline 1 & 0 & 0 \\
2 & 5 & 14.71 \\
3 & 9 & 26.47 \\
4 & 6 & 17.65 \\
5 & 9 & 26.47 \\
6 & 3 & 8.82 \\
7 & 2 & 5.88 \\
\hline Total & 34 & 100 \\
Mean & 4.059 & \\
Std. Dev. & 1.434 & \\
& & \\
\hline
\end{tabular}

Table A33 Podesta Experience (Descriptive Statistics)

\begin{tabular}{lll}
\hline Likert Scale & Frequency & Percent \\
\hline 1 & 0 & 0 \\
2 & 0 & 0 \\
3 & 0 & 0 \\
4 & 1 & 2.33 \\
5 & 1 & 2.33 \\
6 & 11 & 25.58 \\
7 & 30 & 69.77 \\
\hline Total & 43 & 100 \\
Mean & 6.628 & \\
Std. Dev. & .655 & \\
& & \\
\hline
\end{tabular}

